Prepared in cooperation with the lowa Department of Transportation and lowa Highway Research Board (Project HR-140)

\title{
Flood of August 11-16, 2010, in the South Skunk River Basin, Central and Southeast lowa
}

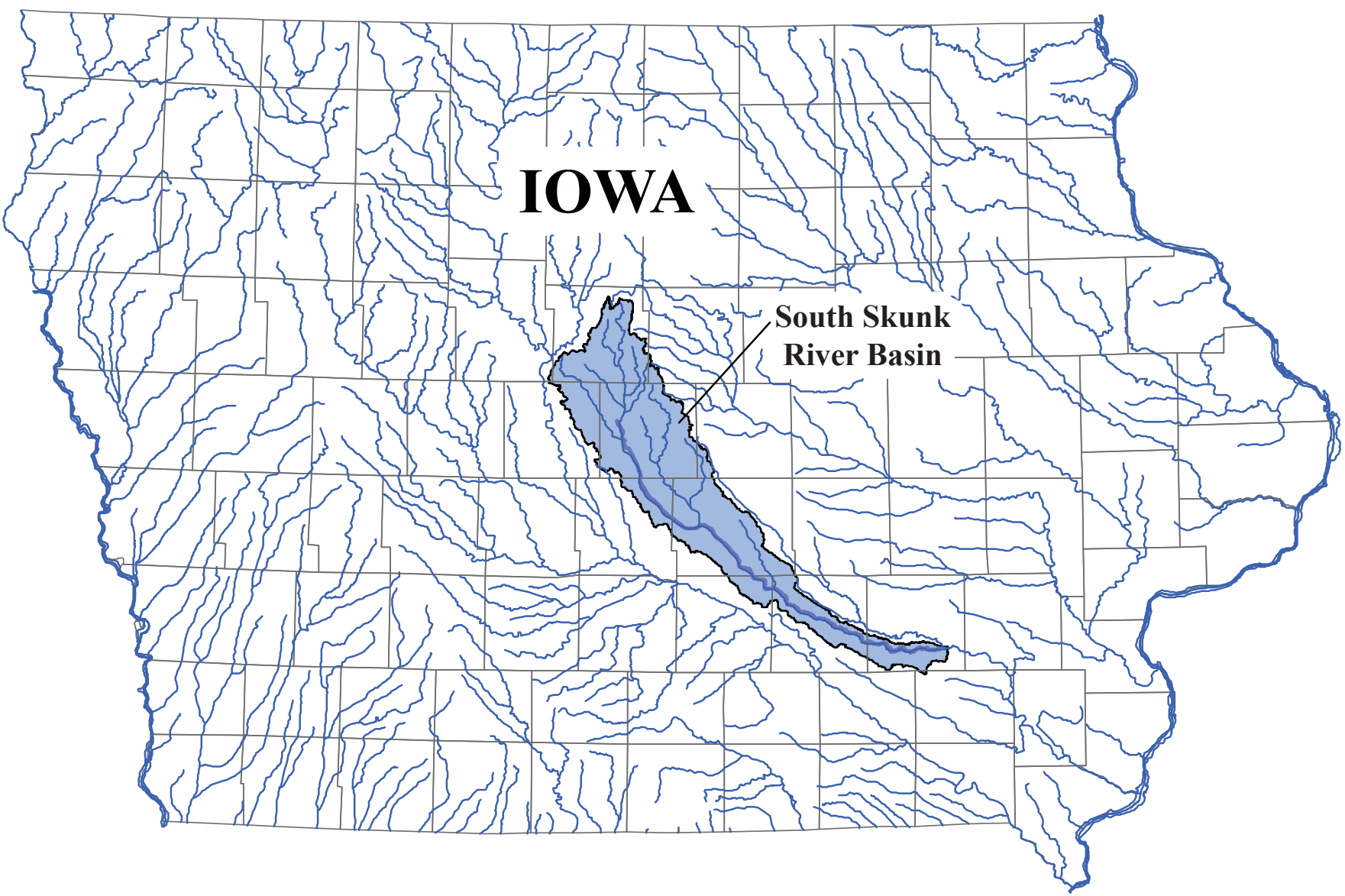

Open-File Report 2012-1202 



\section{Flood of August 11-16, 2010, in the South Skunk River Basin, Central and Southeast lowa}

By Kimberlee K. Barnes and David A. Eash

Prepared in cooperation with the lowa Department of Transportation and lowa Highway Research Board (Project HR-140)

Open-File Report 2012-1202 


\title{
U.S. Department of the Interior \\ KEN SALAZAR, Secretary \\ U.S. Geological Survey \\ Marcia K. McNutt, Director
}

\author{
U.S. Geological Survey, Reston, Virginia: 2012
}

For more information on the USGS - the Federal source for science about the Earth, its natural and living resources, natural hazards, and the environment, visit http://www.usgs.gov or call 1-888-ASK-USGS.

For an overview of USGS information products, including maps, imagery, and publications, visit http://www.usgs.gov/pubprod

To order this and other USGS information products, visit http://store.usgs.gov

Any use of trade, firm, or product names is for descriptive purposes only and does not imply endorsement by the U.S. Government.

Although this information product, for the most part, is in the public domain, it also may contain copyrighted materials as noted in the text. Permission to reproduce copyrighted items must be secured from the copyright owner.

Suggested citation:

Barnes, K.K., and Eash, D.A., 2012, Flood of August 11-16, 2010, in the South Skunk River Basin, central and southeast lowa: U.S. Geological Survey Open-File Report 2012-1202, 27 p. with appendix. 


\section{Acknowledgments}

The authors express their gratitude to Harry Hillaker, State Climatologist, lowa Department of Agriculture and Land Stewardship, for providing an isohyetal map of rainfall for the 72-hour period ending 5:00 a.m. on August 11, 2010; Bonnie Shepard, National Flood Insurance Program Bureau and Statistical Agent, Federal Emergency Management Agency, for providing private property damage claims for eight counties in lowa; and Dennis Harper, State Hazard Mitigation Officer, lowa Homeland Security and Emergency Management Division, for providing public assistance project costs for eight counties in lowa.

The authors also recognize U.S. Geological Survey employees Mike Linhart and Jim Caldwell for collecting field data for the determination of water-surface and bench-mark elevations listed in this report. 


\section{Contents}

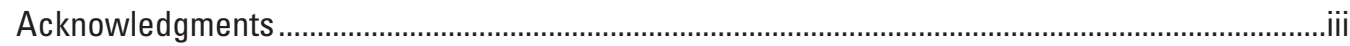

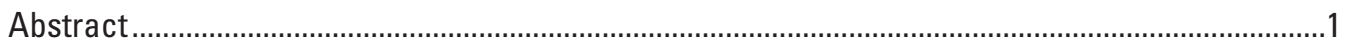

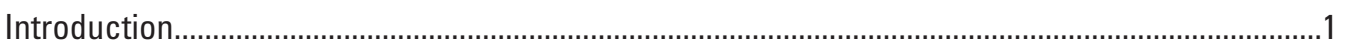

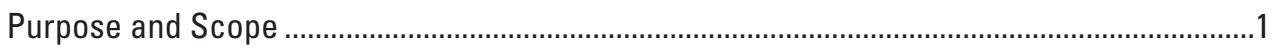

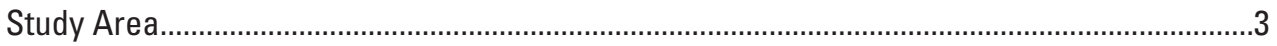

Annual Flood Probability .......................................................................................................

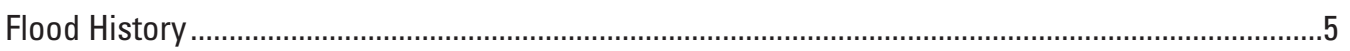

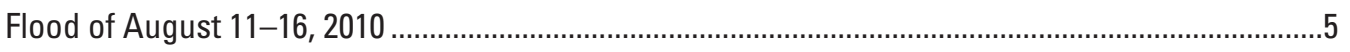

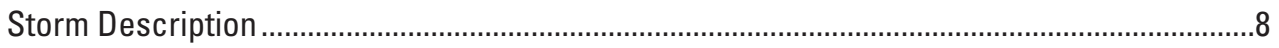

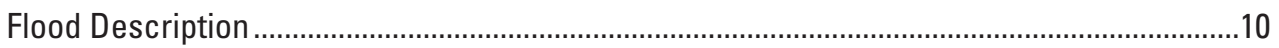

Chronology of Flood Effects ................................................................................................11

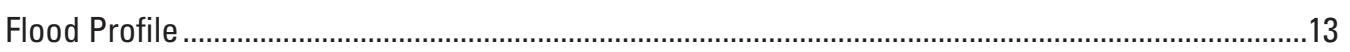

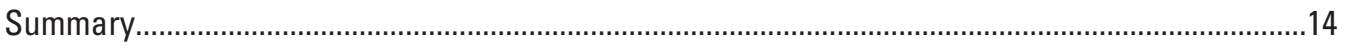

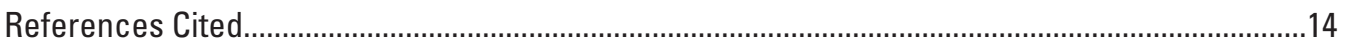

Appendix. List of Bench Marks and Reference Points.................................................................

\section{Figures}

1. Map showing South Skunk River Basin and lines of equal rainfall for 72 hours

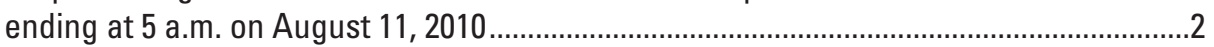

2. Map showing South Skunk River Basin and landform regions of lowa .............................4

3. Graphs showing hourly rainfall for August 8-11, 2010, at four rain gages in the South Skunk River Basin and vicinity.........................................................................

4. Graphs showing discharge hydrographs for four streamgages on the South Skunk

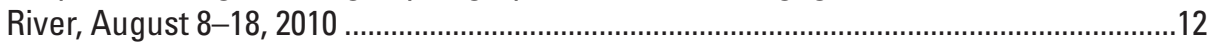

5. Graph showing profile of the August 11-16, 2010, flood for the South Skunk River, river miles 4 to 133 .

6. Graph showing profile of the August 11-16, 2010, flood for the South Skunk River,

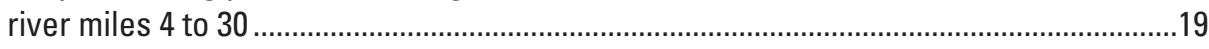

7. Graph showing profile of the August 11-16, 2010, flood for the South Skunk River,

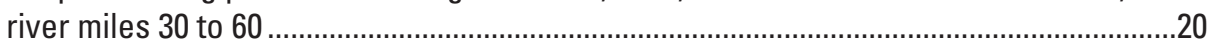

8. Graph showing profile of the August 11-16, 2010, flood for the South Skunk River,

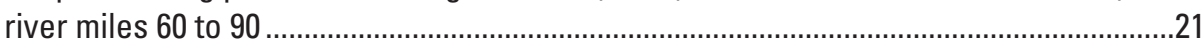

9. Graph showing profile of the August 11-16, 2010, flood for the South Skunk River, river miles 90 to 120

10. Graph showing profile of the August 11-16, 2010, flood for the South Skunk River, river miles 120 to 133 . 


\section{Tables}

1. National Flood Insurance Program Bureau and Statistical Agent lowa claims closed with payment for selected counties for disaster number 1930,

August 11-16, 2010, as of February 28, 2011....................................................................

2. Iowa Public Assistance Program project costs for selected counties for disaster number 1930, June-August 2010, as of April 29, 2011

3. Maximum stages and discharges for 2010 and selected largest-flood years, and the corresponding annual flood-probability ranges, at streamgages in the South Skunk River Basin, lowa .

4. Annual flood probability and equivalent flood recurrence interval for selected probabilities

5. Twenty-four-hour rainfall amounts and greatest 48- and 72-hour rainfall totals at selected rain gages in central, south-central, and southeast lowa during August 8-11, 2010

6. Magnitude and annual probability of theoretical rainfall amounts for selected storm periods in the Central, South-Central, and Southeast lowa Climatological Divisions

7. Locations and elevations of high-water marks used in the South Skunk River flood profile of August 11-16, 2010

1-1. Bench marks and reference points used in the August 11-16, 2010, South Skunk River flood profile.

\section{Conversion Factors and Datums}

Inch/Pound to SI

\begin{tabular}{lcl}
\hline \multicolumn{1}{c}{ Multiply } & By & \multicolumn{1}{c}{ To obtain } \\
\hline inch (in.) & Length & \\
foot $(\mathrm{ft})$ & 2.54 & centimeter $(\mathrm{cm})$ \\
mile $(\mathrm{mi})$ & 0.3048 & meter $(\mathrm{m})$ \\
\hline & 1.609 & kilometer $(\mathrm{km})$ \\
\hline square mile $\left(\mathrm{mi}^{2}\right)$ & Area & \\
\hline & 2.590 & square kilometer $\left(\mathrm{km}^{2}\right)$ \\
\hline cubic foot per second $\left(\mathrm{ft}^{3} / \mathrm{s}\right)$ & Flow rate & \\
\hline
\end{tabular}

Elevation or vertical coordinate information is referenced to the National Geodetic Vertical Datum of 1929 (NGVD 29). Elevation refers to distance above or below NGVD 29. NGVD 29 can be converted to the North American Vertical Datum of 1988 by using the National Geodetic Survey conversion utility (U.S. Department of Commerce, National Oceanic and Atmospheric Administration, and National Climatic Data Center, 2004).

Horizontal coordinate information is referenced to the North American Datum of 1983 (NAD 83).

Map projections are Universal Transverse Mercator, Zone 15.

Water year is the 12-month period from 0ctober 1 through September 30. The water year is designated by the calendar year in which the water year ends and that includes 9 of the 12 months. Thus, the water year ending September 30, 2010, is called the "2010 water year." 



\title{
Flood of August 11-16, 2010, in the South Skunk River Basin, Central and Southeast lowa
}

\author{
By Kimberlee K. Barnes and David A. Eash
}

\section{Abstract}

Severe thunderstorm activity during August 8-11, 2010 in central and southeast Iowa resulted in major flooding from August 11-16, 2010, in the South Skunk River Basin. Rain gages at Ames and Story City recorded 96-hour rainfall amounts of 9.61 and 8.70 inches, respectively. The majority of the rainfall occurred during a 52-hour period, beginning late at night on August 8. Within the South Skunk River Basin, peak discharges of 14,800 cubic feet per second (annual floodprobability estimate of 0.2 to 1 percent) at the 05470000 South Skunk River near Ames, Iowa streamgage; of 36,200 cubic feet per second (annual flood-probability estimate of less than 0.2 percent) at the 05471000 South Skunk River below Squaw Creek near Ames, Iowa streamgage (both on August 11, 2010); and of 24,000 cubic feet per second (annual flood-probability estimate of 0.2 to 1 percent) at 05471050 South Skunk River at Colfax, Iowa streamgage on August 14 are the largest floods on record for these sites. Peak discharges at 05470500 Squaw Creek at Ames, Iowa streamgage of 22,400 cubic feet per second (annual flood-probability estimate of less than 0.2 percent) on August 11; and at 05471500 South Skunk River near Oskaloosa, Iowa streamgage, of 25,200 cubic feet per second (annual flood- probability estimate of 1 to 2 percent) on August 16 are the second highest floods on record. This report provides a description of the watershed, the thunderstorms, the flooding, and a profile of high-water marks measured at 20 locations along the South Skunk River between County Road V67/280th Avenue, northeast of Ollie in Keokuk County and West Riverside Road in Ames, a distance of 128 river miles.

\section{Introduction}

This report is part of an on-going program of publishing water-surface profiles for major floods on streams in Iowa. The program is managed by the U.S. Geological Survey (USGS) in cooperation with the Iowa Department of Transportation (Iowa DOT) and the Iowa Highway Research Board (Project HR-140).
Following record statewide precipitation in June and July 2010, three consecutive nights of strong thunderstorms August 8-11, 2010, caused record flooding on the South Skunk River. New maximum peak discharges were recorded on August 11, 2010, at streamgages 05470000 South Skunk River near Ames (fig. 1, site 4) and 05471000 South Skunk River below Squaw Creek near Ames (fig. 1, site 6). The August 8-11 storms also caused a new maximum peak discharge on August 14, 2010, at streamgage 05471050 South Skunk River at Colfax (fig. 1, site 8).

Because of flooding in the South Skunk River Basin, the counties of Boone, Hamilton, Jasper, Keokuk, Mahaska, Marion, Polk, and Story were added to a State disaster proclamation during August 13-23, 2010, which authorized implementation of the State Individual Assistance Grant Program to assist eligible residents of those counties (Iowa Homeland Security and Emergency Management, 2010). A Federal disaster declaration (number 1930) was issued on July 29, 2010, to help the citizens of Iowa recover from losses caused by severe storms, flooding, and tornados for the incident period June 1 to August 31, 2010 (Federal Emergency Management Agency, 2010). The Federal disaster declaration requested individual assistance for 38 counties and public assistance for 59 counties in Iowa. Private property damage claims reported for residential and nonresidential buildings in eight selected counties in central and southeast Iowa are shown in table 1 (Bonnie Shepard, Federal Emergency Management Agency, National Flood Insurance Program Bureau and Statistical Agent, written commun., May 2011). Approved public assistance costs (assistance to local governments for the repair of disaster-damaged public facilities) for the same eight counties in Iowa are shown in table 2 (Dennis Harper, Iowa Homeland Security and Emergency Management Division, State Hazard Mitigation Officer, written commun., April 2011).

\section{Purpose and Scope}

Flood-peak and water-surface-elevation profile information is needed for the economical, safe location, and design of bridges and other structures on or over streams and the adjacent flood plains. Defining the limits of flood inundation and establishing encroachment limits on flood plains are related 


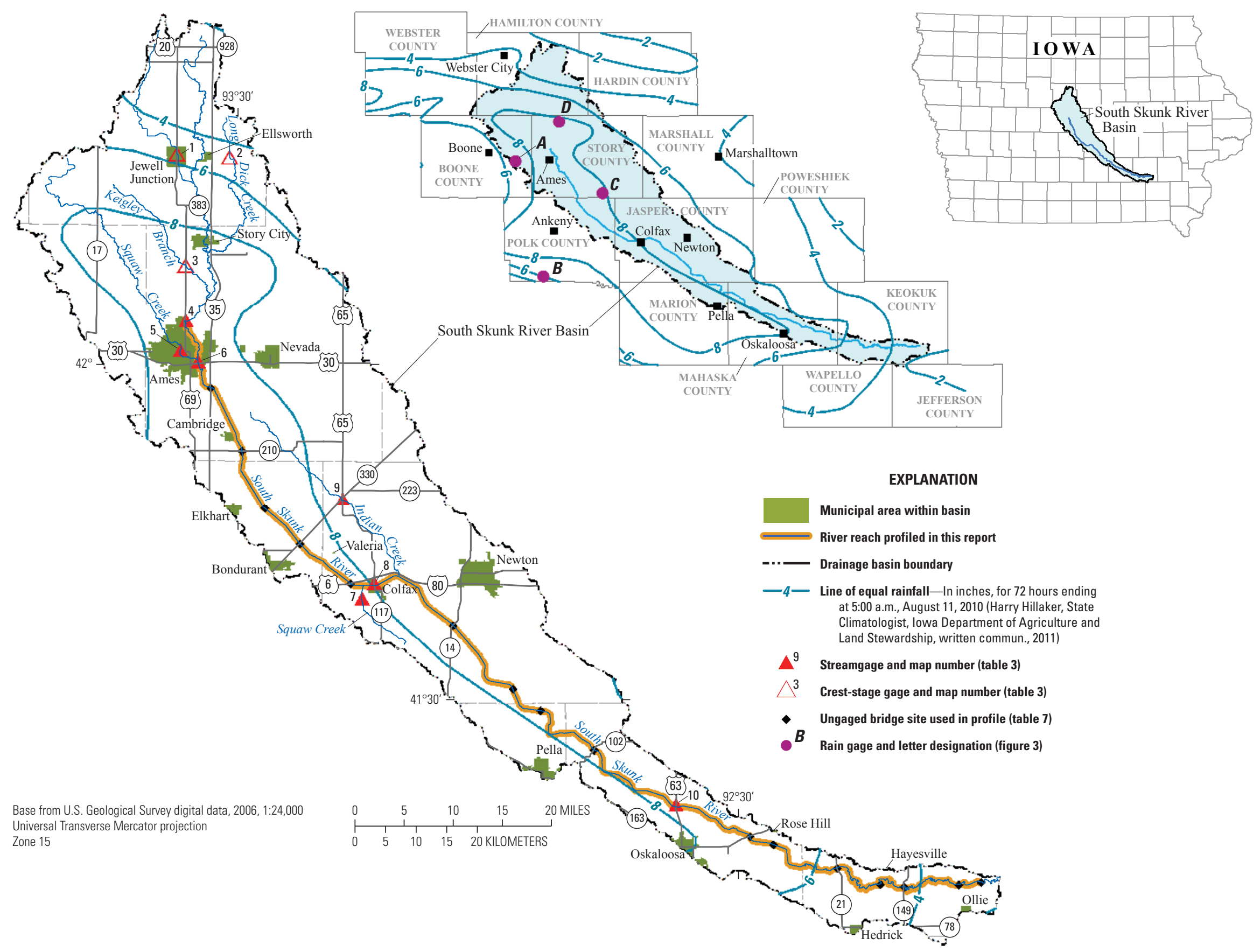

Figure 1. South Skunk River Basin and lines of equal rainfall for 72 hours ending at 5 a.m. on August 11, 2010. 
issues dependent on this information. Data for major floods are needed to compute annual flood-probability discharges and to calibrate water-surface-elevation profile models for sites along streams. A list of other USGS flood-profile reports for Iowa can be obtained by accessing http://ia.water.usgs.gov/projects/ profiles/.

Table 1. National Flood Insurance Program Bureau and Statistical Agent lowa claims closed with payment for selected counties for disaster number 1930, August 11-16, 2010, as of February 28, 2011.

[Bonnie Shepard, Federal Emergency Management Agency, National Flood Insurance Program Bureau and Statistical Agent, written commun., May 2011; $\mathrm{NC}$, no claims]

\begin{tabular}{lcc}
\hline \multicolumn{1}{c}{ County } & Number of claims & $\begin{array}{c}\text { Damage payment } \\
\text { (dollars) }\end{array}$ \\
\hline Boone & 1 & 57,436 \\
Hamilton & $\mathrm{NC}$ & $\mathrm{NC}$ \\
Jasper & 14 & 534,374 \\
Keokuk & $\mathrm{NC}$ & $\mathrm{NC}$ \\
Mahaska & 3 & 18,153 \\
Marion & 1 & 1,515 \\
Polk & 53 & $1,392,352$ \\
Story & 43 & $5,983,435$ \\
Total & $\mathbf{1 1 5}$ & $\mathbf{7 , 9 8 7 , 2 6 5}$ \\
\hline
\end{tabular}

This report provides rainfall information for August 8-11, 2010; flooding information during August 11-16, 2010, in the South Skunk River Basin; and estimated annual floodprobability ranges at seven continuous-record streamgages and two crest-stage gages (CSG) in the basin. High-water marks (HWMs) at selected sites along the South Skunk River are presented in a flood profile from County Road V67/280th Avenue northeast of Ollie (not shown in fig. 1) in Keokuk County to USGS streamgage 05470000 on West Riverside Road (not shown in fig. 1) in Ames, a distance of 128 river miles.

\section{Study Area}

The South Skunk River originates near the center of the State in Hamilton County and flows southeasterly about 185 miles through the cities of Ellsworth, Story City, Ames, Cambridge, and Colfax, to its confluence with the North Skunk River in Keokuk County (fig. 1). The confluence of the North Skunk and South Skunk Rivers forms the Skunk River, which is a tributary of the Mississippi River. The drainage area of the South Skunk River at the confluence is 1,842 square miles $\left(\mathrm{mi}^{2}\right)$ and lies in parts of 12 counties. Land use in the basin is predominately agricultural. The channel of the South Skunk River has been straightened from near Ames downstream through Mahaska County. Through this reach, the flood plain of the South Skunk River is as much as 2 miles (mi) wide (Heinitz and Wiitala, 1978). The drainage basin, the river reach profiled, the location of USGS streamgages within this river basin, and the location of bridge sites used in the August 11-16, 2010, flood profile are shown in figure 1.

Table 2. lowa Public Assistance Program project costs for selected counties for disaster number 1930, June-August 2010, as of April 29, 2011.

[Dennis Harper, Iowa Homeland Security and Emergency Management Division, State Hazard Mitigation Officer, written commun., April 29, 2011; $\mathrm{NC}$, no claims]

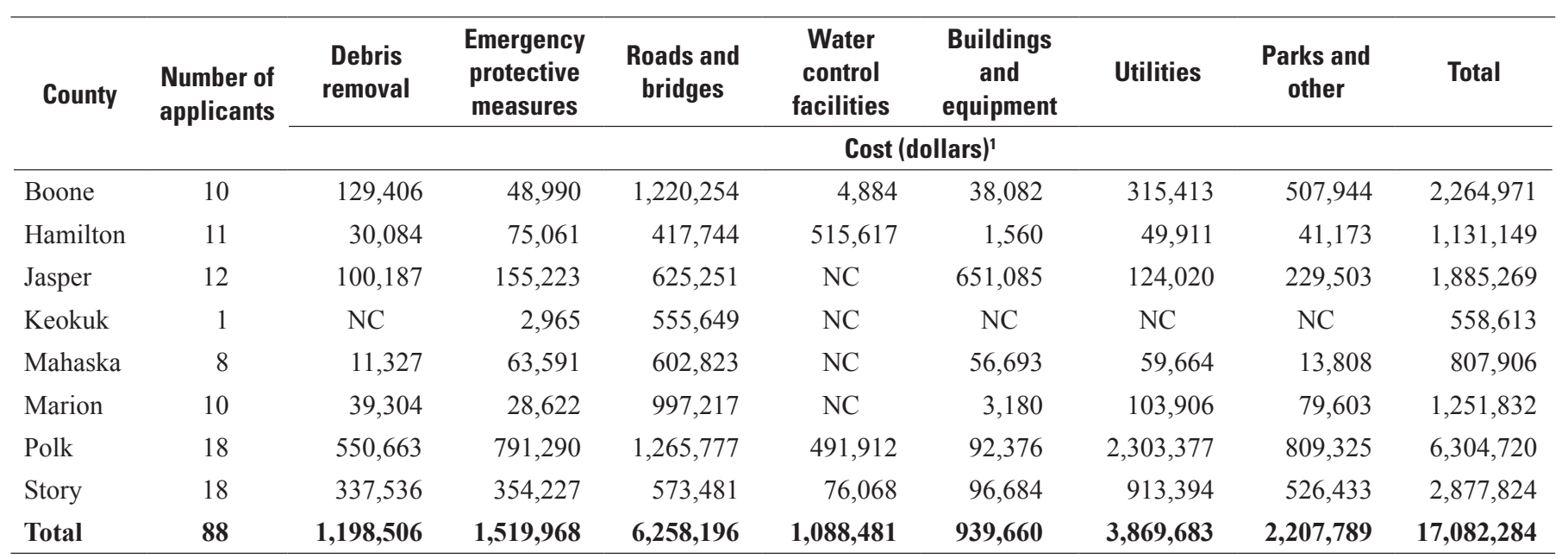

${ }^{1}$ Cost rounded to whole dollars. 
The South Skunk River Basin lies within two of Iowa's landform regions (fig. 2), the Des Moines Lobe and the Southern Iowa Drift Plain. The Des Moines Lobe landform region is characteristic of a young, postglacial landscape that is unique with respect to the rest of the State (Prior, 1991). The Des Moines Lobe generally comprises low relief terrain, accentuated by natural lakes, potholes, and marshes, where surfacewater drainage typically is poorly defined and sluggish. Soils of the Des Moines Lobe generally consist of friable, calcareous loam glacial till with thick deposits of compact, uniform pebbly loam (Oschwald and others, 1965; Prior, 1991). The Southern Iowa Drift Plain is characteristic of an older, postglacial landscape that has eroded to form a steeply to gently rolling topography and a well-established drainage system (Prior, 1991). The transition boundary between these two landform regions is in northwestern Jasper and southwestern Marshall Counties (figs. 1 and 2). Extensive descriptions of the landform regions are available from Prior (1991) and Prior and others (2009).
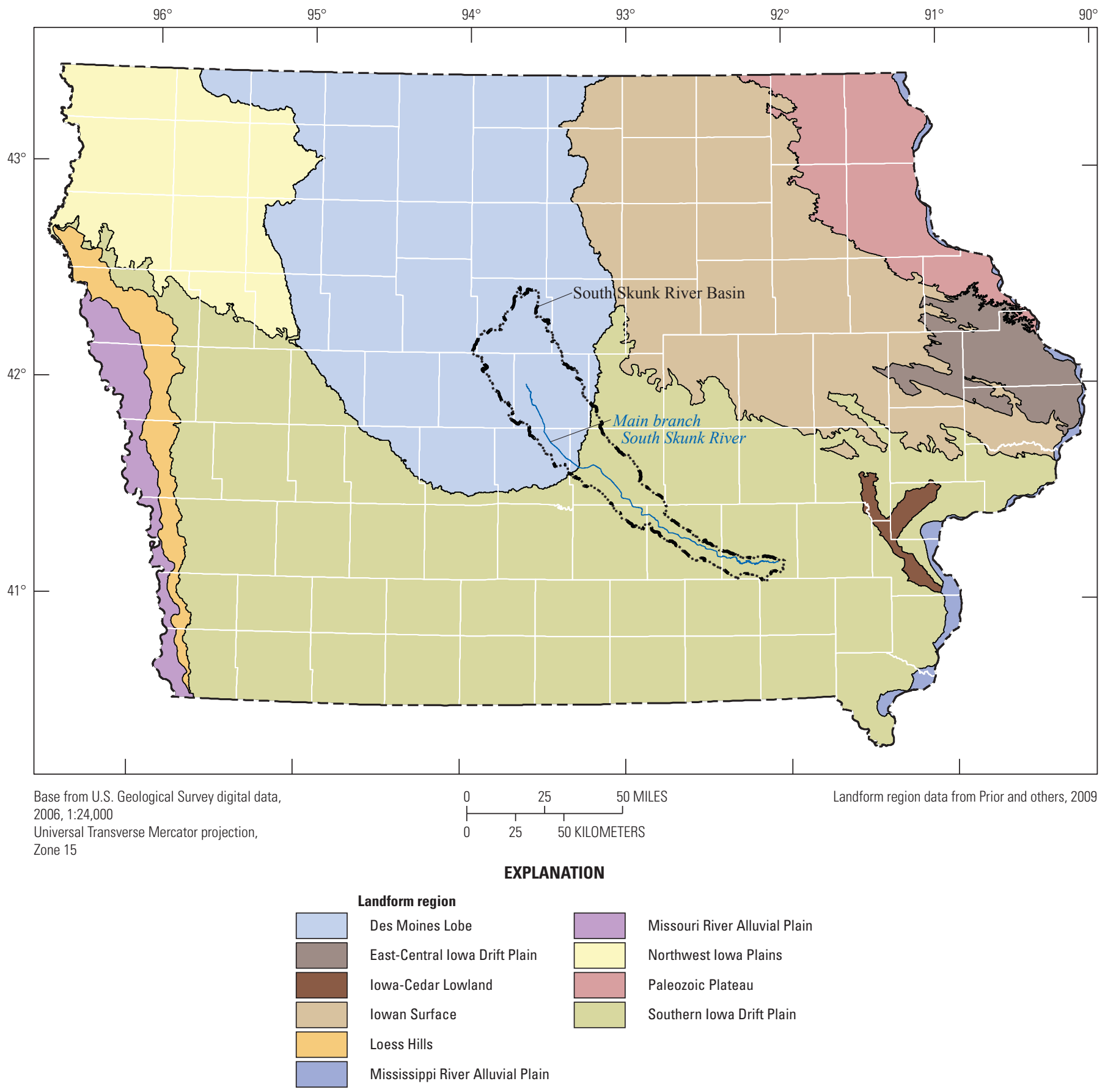

Figure 2. South Skunk River Basin and landform regions of lowa. 


\section{Annual Flood Probability}

Annual flood probability, also referred to as annual exceedance probability, is an estimate of the likelihood of a flood of a specific magnitude occurring in any year, and an annual flood-probability range expresses the uncertainty of estimating precise annual flood probabilities. The reporting ranges are as follows: greater than 10 percent, 4 to 10 percent, 2 to 4 percent, 1 to 2 percent, 0.2 to 1 percent, and less than 0.2 percent. The range is determined from the estimated annual flood-probability discharges that bracket the observed flood-peak discharge. If the observed flood-peak discharge is the same value as an estimated annual flood-probability discharge, the lower annual flood-probability range is used. In the "Flood Description" section, flood discharges and their respective annual flood-probability ranges are discussed and are listed in table 3 . Unless noted otherwise, annual floodprobability estimates listed in table 3 were computed using the Weighted Independent Estimates (WIE) program (Cohn and others, 2012), following guidelines in appendix 8 of Bulletin 17B (Interagency Advisory Committee on Water Data, 1982). The WIE program uses the variance and estimate of the Bulletin 17B annual streamgage-probability analysis, and the variance and estimate of the regional-regression annual probability calculation (Eash, 2001) to compute a weighted estimate and variance at a streamgage.

Annual flood probabilities change as streamflow records get longer. Bulletin 17B annual probability analyses are computed for streamgages using annual peak-discharge data. As additional annual peak discharges are measured at streamgages, Bulletin 17B annual flood-probability estimates are updated and become more statistically reliable. A minimum of 10 years of record is recommended to compute Bulletin 17B annual streamgage-probability estimates (Interagency Advisory Committee on Water Data, 1982).

Annual flood probabilities formerly were reported as flood recurrence intervals expressed in years. For example, a 1-percent annual flood-probability discharge is the same as the 100-year recurrence-interval flood discharge (Holmes and Dinicola, 2010); however, because of widespread confusion caused in recent years by two or more " 100 -year floods" occurring in a period of much less than 100 years, the scientific and engineering community has begun expressing the annual likelihood of occurrence of flood discharges as a probability. Percent probability is the reciprocal of the recurrence interval multiplied by 100 . Selected annual flood probabilities and equivalent flood recurrence intervals are listed in table 4 . Although the annual probability is an estimate of the likelihood of a flood discharge of a specific magnitude occurring in any year, more than one flood discharge with a specific magnitude and annual probability could occur in the same year. For example, streamgage 05470000 South Skunk River near Ames (fig. 1, site 4) had a theoretical 1-percent annual flood-probability discharge of 9,090 cubic feet per second $\left(\mathrm{ft}^{3} / \mathrm{s}\right)$ computed following the 1993 flood (Eash, 1997). During 1993, however, a flood-peak discharge of $11,100 \mathrm{ft}^{3} / \mathrm{s}$ occurred on July 9 , and another flood-peak discharge of $11,200 \mathrm{ft}^{3} / \mathrm{s}$ occurred on August 16 (table 3). Thus, two floods that theoretically each had less than a 1-percent chance of occurring during any year occurred at this site in the same year. Revised annual flood probabilities of 1 to 2 percent are now estimated for these two 1993 floods based on a longer period of record (table 3). This change in the annual flood-probability estimates for the 1993 floods demonstrates the uncertainty in the estimates and how the estimates may change as the annual peak-discharge record becomes longer.

\section{Flood History}

Continuous records of streamflow have been collected in the South Skunk River Basin since as early as May 1919 at streamgage 05470500, Squaw Creek at Ames (fig. 1, site 5). Minimal information is available about floods before this time. Additional information about flooding in the South Skunk River Basin is available in U.S. Army Corps of Engineers' (USACE) flood plain information reports $(1966,1975)$, Lara and Heinitz (1976), Heinitz and Wiitala (1978), and Einhellig and Eash (1996). At the time, the flood of June 1975 was considered to have caused the greatest urban flood damage in the history of the South Skunk River Basin (Heinitz and Wiitala, 1978). The flood of May 1944 is the largest known flood in the South Skunk River Basin. A peak discharge of 37,000 ft $\mathrm{ft}^{3} / \mathrm{s}$ (annual flood-probability estimate of less than 0.2 percent) was recorded at streamgage 05471500 South Skunk River near Oskaloosa (fig. 1, site 10; table 3).

Peak stages and discharges, and the corresponding annual flood-probability ranges for the largest known floods, including the August 2010 flood, are listed in table 3 for streamgages in the South Skunk River Basin. The streamgages listed in table 3 also are listed in the USGS National Water Information System (NWIS) database, and users may obtain surface-water data for Iowa streamgages, including information on types of data available and years of data collection (U.S. Geological Survey, 2011a).

\section{Flood of August 11-16, 2010}

The flood of August 11-16, 2010, is one of the greatest floods on record in the South Skunk River Basin. The 2010 flood is the largest flood on record for three streamgages. Streamgage 05470000 South Skunk River near Ames (fig. 1, site 4) had a peak discharge of $14,800\left(\mathrm{ft}^{3} / \mathrm{s}\right)$, with an annualflood probability estimate of 0.2 to 1 percent. Streamgage 05471000 South Skunk River below Squaw Creek near Ames (fig. 1, site 6) had a peak discharge of $36,200 \mathrm{ft}^{3} / \mathrm{s}$ (annual flood-probability estimate of less than 0.2 percent). Streamgage 05471050 South Skunk River at Colfax (fig. 1, site 8) had a peak discharge of $24,000 \mathrm{ft}^{3} / \mathrm{s}$ (annual floodprobability estimate of 0.2 to 1 percent). 
Table 3. Maximum stages and discharges for 2010 and selected largest-flood years, and the corresponding annual flood-probability ranges, at streamgages in the South Skunk River Basin, lowa.

$\left[\mathrm{mi}^{2}\right.$, square miles; $\mathrm{ft}$, feet; $\mathrm{ft}^{3} / \mathrm{s}$, cubic feet per second; $\left(\mathrm{ft}^{3} / \mathrm{s}\right) / \mathrm{mi}^{2}$, cubic feet per second per square mile; --, not determined; >, greater than; <, less than $]$

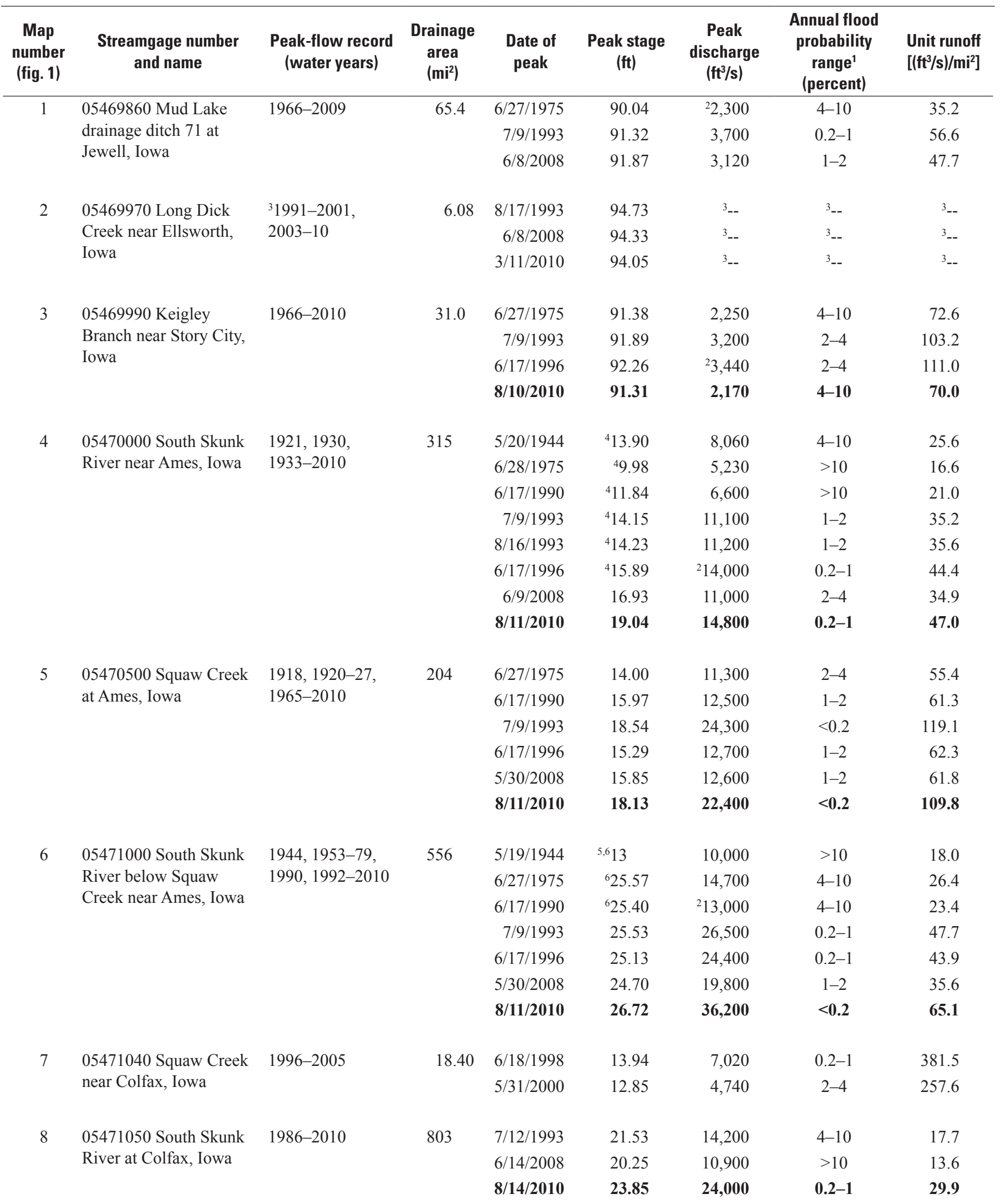


Table 3. Maximum stages and discharges for 2010 and selected largest-flood years, and the corresponding annual flood-probability ranges, at streamgages in the South Skunk River Basin, lowa.-Continued

$\left[\mathrm{mi}^{2}\right.$, square miles; $\mathrm{ft}$, feet; $\mathrm{ft}^{3} / \mathrm{s}$, cubic feet per second; $\left(\mathrm{ft}^{3} / \mathrm{s}\right) / \mathrm{mi}^{2}$, cubic feet per second per square mile; --, not determined; >, greater than; <, less than]

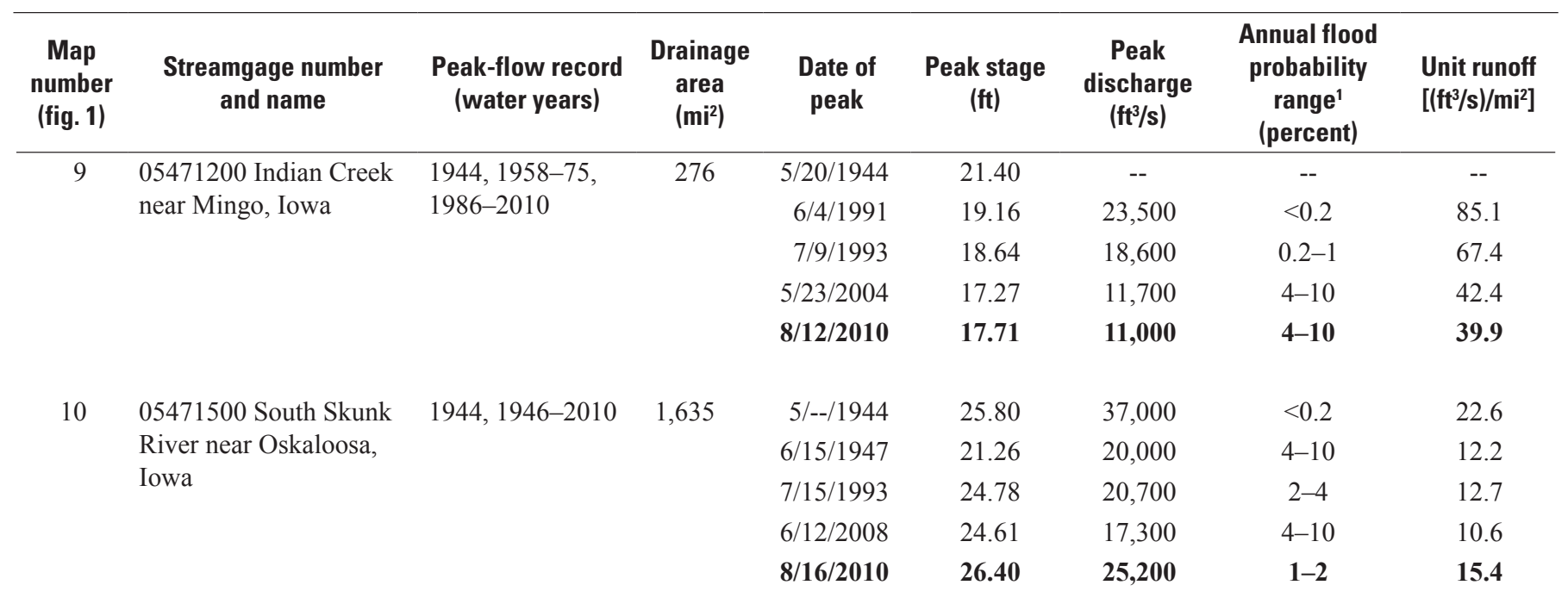

\footnotetext{
${ }^{1}$ Annual flood-probability ranges reflect the uncertainty of estimating annual flood-probability discharges. The annual flood probability is calculated using established techniques but then reported in one of the following ranges: greater than 10 percent, 4 to 10 percent, 2 to 4 percent, 1 to 2 percent, 0.2 to 1 percent, and less than 0.2 percent. Unless noted otherwise, annual flood-probability ranges are based on a weighted average of two independent probability estimates. The WIE (weighted independent estimates) program was used to estimate annual flood probabilities following guidelines in appendix 8 of Bulletin 17B (Interagency Advisory Committee on Water Data, 1982; Cohn and others, 2012). The WIE program uses the variance and estimate of the Bulletin 17B annual streamgage-probability analysis and the variance and estimate of the regional-regression annual probability calculation (Eash, 2001) to compute a weighted probability estimate and variance at a streamgage.

${ }^{2}$ Dishcarge is an estimate (U.S. Geological Survey, 2005).

${ }^{3}$ Annual-peak discharges are not determined because stage-discharge relation is not determined.

${ }^{4}$ Prior to Oct. 1, 2003, streamgage at different site and at datum $5.00 \mathrm{ft}$ higher.

${ }^{5}$ Prior to Oct. 1, 1973, at datum $10.00 \mathrm{ft}$ higher.

${ }^{6}$ Prior to Oct. 1991, at site $500 \mathrm{ft}$ upstream.
}

At streamgages 05470500 Squaw Creek at Ames (fig. 1, site 5) and 05471500 South Skunk River near Oskaloosa (fig. 1, site 10), the 2010 flood is the second largest flood on record. Streamgage 05470500 Squaw Creek at Ames had a peak discharge of $22,400 \mathrm{ft}^{3} / \mathrm{s}$ (annual floodprobability estimate of less than 0.2 percent). Streamgage 05471500 South Skunk River near Oskaloosa had a peak discharge of $25,200 \mathrm{ft}^{3} / \mathrm{s}$ (annual flood-probability estimates of 1 to 2 percent). Periods of peak-flow record for streamgages in the South Skunk River Basin are presented in table 3.
Table 4. Annual flood probability and equivalent flood recurrence interval for selected probabilities.

\begin{tabular}{cc}
\hline $\begin{array}{c}\text { Annual flood probability } \\
\text { (percent) }\end{array}$ & $\begin{array}{c}\text { Recurrence interval } \\
\text { (years) }\end{array}$ \\
\hline 20 & 5 \\
10 & 10 \\
4 & 25 \\
2 & 50 \\
1 & 100 \\
0.5 & 200 \\
0.2 & 500 \\
\hline
\end{tabular}




\section{Storm Description}

The flood of August 11-16, 2010, was the result of three consecutive nights of local, heavy rain in central Iowa from August 8-11. The storms were part of an exceptionally wet period for Iowa from June through September 2010 that followed a wetter than normal first 6 months of the year. A new statewide rainfall record of 10.39 inches (in.) was set for the month of June; the old record of 10.33 in. occurred in 1947. Overall, 2010, with an average statewide rainfall of 45.10 in., was the second wettest year in Iowa in 138 years of record (Hillaker, 2010a). Although rainfall during July and August 2010 was not as great as in June, it was locally more intense for a short period of time, which resulted in greater flooding; the greatest rain event in August occurred from August 8-11, when the Ankeny rain gage (fig. 1) officially recorded 9.86 in. and the Ames rain gage recorded $9.61 \mathrm{in}$. during these 3 nights. A new record maximum total rainfall of $13.71 \mathrm{in}$. was set for the month of August at Ankeny. The old record was 12.87 in., set in 1993 among 60 years of records (Hillaker, 2010b).

The following rainfall and flood information is from the U.S. Department of Commerce, National Oceanic and Atmospheric Administration, and National Climatic Data Center (2010a) search terms Iowa, $8 / 8 / 2010$ to $8 / 16 / 2010$, and flood were entered to obtain a list of 113 flood events; the following quotes were obtained from event numbers (16) Youngstown,

(23) Ames, and (92) Ames:

"The very wet weather pattern of June and July continued into the first two weeks of August. Central Iowa was hardest hit by rainfall with three consecutive nights of torrential rains on the 8th, 9th and 10th. A swath of 2 to 5 inch rainfall extended from west central, through central, into parts of southeast Iowa. Ankeny recorded 9.86 inches of rain over these three nights while Ames had 9.61 inches. Record flood impacted much of Story, Polk, Jasper and Mahaska counties. The flooding was major along the Skunk and parts of the lower Des Moines River basin. Following the flash flooding of the 10th and 11th, major river flooding continued. Significant crop losses occurred because of the high water flooding fields for several days. Major damage was done along the Skunk Basin from Ames, through Colfax. Numerous roads were covered with flowing water of 1 to 2 feet in depth. Water from the South Skunk River completely covered portions of US Highway 30 near Ames and Interstate 35 just south of Ames. Highway 117 just south of Interstate 80 was closed and barricaded due to water over the road from the South Skunk near Colfax. The flash flooding claimed one life in central Iowa. Three vehicles were swept into the water of Mud Creek near Altoona in Polk County. There were 11 people involved. Major damage was done to several buildings on the Iowa State Campus. Hilton Coliseum reported 4 to 6 feet of water inside flooding the stadium and basketball floor. Cy Stephens Auditorium also report[ed] water in the mechanical building up to the 1st floor. The water system was knocked out in Ames, and threatened in Colfax."

Hourly rainfall amounts for August 8-11, 2010, for rain gages at Ames, Des Moines, Maxwell, and Story City (site A, B, C, D, respectively, figure 1) are shown in figure 3 (U.S. Department of Commerce, National Oceanic and Atmospheric Administration, and National Climatic Data Center, 2010b). The graphs provide a general indication of the timing and intensity of the rainfall in the South Skunk River Basin. The greatest 1-hour rainfall intensity of $2.4 \mathrm{in}$. at Ames 8 WSW, ended at midnight on August 8, 2010 (fig. 3A). Data from the four rain gages (fig. 3) indicate that much of the rainfall occurred from 10 p.m. on August 8 to 1 a.m. on August 11, and also indicate that Story City recorded the greatest 24-hour and 48-hour rainfall of $6.3 \mathrm{in.}$ and $7.7 \mathrm{in.}$ respectively.

An isohyetal map of the areal distribution of rainfall for the 72-hour period beginning at 5 a.m. on August 8, 2010, and ending at $5 \mathrm{a} . \mathrm{m}$. on August 11, 2010, is shown in figure 1; data were provided by Harry Hillaker, State Climatologist, Iowa Department of Agriculture and Land Stewardship (written commun., November 2011). The isohyetal map shows a band of $8 \mathrm{in}$. of rainfall in the headwaters and along the South Skunk River Basin from Story City, south through Ames and Ankeny, then southeast through Oskaloosa. Each 24-hour rainfall amount from August 8 to August 11, 2010, for 12 selected rain gages in central, south-central, and southeast Iowa is listed in table 5 (Hillaker, 2010c). The 72-hour rainfall total listed in table 5 from August 8-11 is the time period for which the rainfall could be considered as directly contributing to the flooding of August 11-16.

The "Rainfall Frequency Atlas of the Midwest" (Huff and Angel, 1992) provides a table of the mean distribution of theoretical rainfall amounts for climatological divisions in Iowa for selected rain periods and annual probabilities (recurrence intervals). The magnitude and annual probability of theoretical rainfall amounts for selected rain periods (durations), from the table in Huff and Angel (1992), for 3 of the 9 climatological divisions in Iowa pertaining to this report are listed in table 6 . Nine of the 12 rain gages listed in table 5 are in the Central Iowa Climatological Division, 2 are located in the South-central Climatological Division, and 1 is located in the Southeast Climatological Division (Hillaker, 2010c). A map showing the location of climatological divisions in Iowa is in Huff and Angel (1992). The greatest 48-hour rainfalls listed in table 5 equaled or exceeded 6 in. at six rain gages, five of which are located in the Central Climatological Division (Ames 8 WSW, Ankeny, Des Moines Camp Dodge, Maxwell, and Story City), with one rain gage located in the Southeast Climatological Division (Oskaloosa). The annual rainfall probability for greatest 48-hour rainfalls is estimated to be 4 to 10 percent for the Oskaloosa rain gage, 2 to 4 percent for the Ames 8 WSW and Maxwell rain gages, 1 to 2 percent for the Ankeny and 

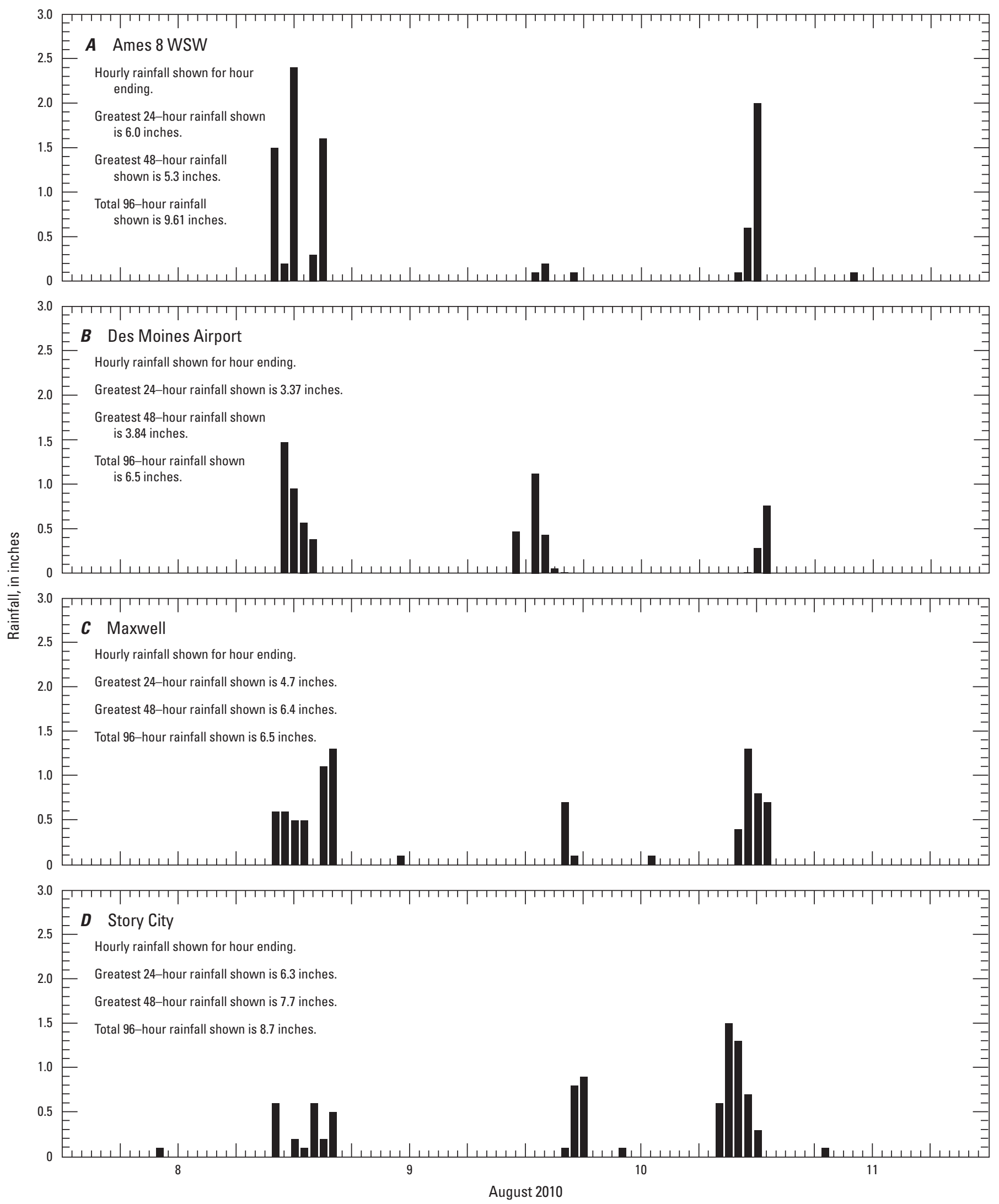

Figure 3. Hourly rainfall for August 8-11, 2010, at four rain gages in the South Skunk River Basin and vicinity (Central Daylight Time; U.S. Dept. of Commerce, National Oceanic and Atmospheric Administration, and National Climatic Data Center, 2010b). 
Table 5. Twenty-four-hour rainfall amounts and greatest 48- and 72-hour rainfall totals at selected rain gages in central, south-central, and southeast lowa during August 8-11, 2010.

\begin{tabular}{|c|c|c|c|c|c|c|c|}
\hline \multirow[b]{2}{*}{ Rain gage } & \multicolumn{5}{|c|}{ 24-hour rainfall, in inches } & \multirow{2}{*}{$\begin{array}{l}\text { Greatest } 48 \text {-hour } \\
\text { rainfall total, } \\
\text { in inches }\end{array}$} & \multirow{2}{*}{$\begin{array}{l}\text { Greatest 72-hour } \\
\text { rainfall total, } \\
\text { in inches }\end{array}$} \\
\hline & $\begin{array}{c}\text { Observation } \\
\text { time }\end{array}$ & $\begin{array}{c}\text { August 8, } \\
2010\end{array}$ & $\begin{array}{c}\text { August 9, } \\
2010\end{array}$ & $\begin{array}{l}\text { August 10, } \\
2010\end{array}$ & $\begin{array}{l}\text { August 11, } \\
2010\end{array}$ & & \\
\hline Ames $5 \mathrm{SE}^{1}$ & 6 a.m. & 0.00 & 5.03 & 0.27 & 4.31 & 5.30 & 9.61 \\
\hline Ames $8 \mathrm{WSW}^{2}$ & midnight & 4.10 & 1.90 & 3.10 & 0.10 & 6.00 & 9.10 \\
\hline Ankeny ${ }^{1}$ & 7 a.m. & 0.00 & 2.90 & 3.30 & 3.66 & 6.96 & 9.86 \\
\hline Boone $^{1}$ & 8 a.m. & 0.00 & 3.85 & 0.42 & 1.63 & 4.27 & 5.90 \\
\hline Des Moines Camp Dodge ${ }^{1}$ & midnight & 2.03 & 2.68 & 3.97 & ${ }^{3} 0.38$ & 6.65 & 8.68 \\
\hline Knoxville $^{1}$ & 6 a.m. & 0.00 & 2.10 & 1.36 & 2.01 & 3.46 & 5.47 \\
\hline Maxwell $^{2}$ & midnight & 1.70 & 3.00 & 3.40 & 0.70 & 6.40 & 8.10 \\
\hline Newton ${ }^{1}$ & 7 a.m. & 0.00 & 2.87 & 1.59 & 2.61 & 4.46 & 7.07 \\
\hline
\end{tabular}

${ }^{1}$ Iowa Climate Review (Hillaker, 2010c).

${ }^{2}$ Hourly Precipitation Data, Iowa, August 2010 (U.S. Department of Commerce, National Oceanic and Atmospheric Administration, and National Climatic Data Center, 2010b).

${ }^{3}$ Estimate (Hillaker, 2010c).

Des Moines Camp Dodge rain gages, and less than 1 percent for the Story City rain gage (table 6).

Annual flood probabilities for various locations in the South Skunk River Basin are listed in table 3 and annual probabilities for rainfall for various locations in the South Skunk River Basin are listed in table 6. Similar to the concept of annual flood probability, annual rainfall probability is an estimate of the likelihood of a rainfall of a specific magnitude and duration occurring in any year; more than one rainfall with a specific magnitude and annual probability could occur in the same year.

\section{Flood Description}

Major flooding occurred August 11-16, 2010, in the South Skunk River Basin as a result of the intense rain that fell during August 8-11. The 2010 peak discharges for 8 streamgages in the South Skunk River Basin are listed in table 3. Also listed in the table are selected historical peak discharges for the largest-flood years.

Hydrographs of instantaneous discharges recorded at the four continuous-record streamgages on the South Skunk River are presented in figure 4. The period shown is August 8 to August 18, 2010. The streamgages record instantaneous values at 15-minute time intervals. Also shown on the hydrographs are lines denoting discharge estimates for selected annual flood probabilities. The annual flood-probability range listed in table 3 for the sites is the range between the annual floodprobability discharges that bracket the flood-peak discharge.
For example, the 2010 peak discharge at streamgage 05470000 South Skunk River near Ames (fig. 1, site 4) falls between the 1-percent and 0.2-percent annual flood-probability estimates (table 3 and fig. 4).

Flooding began on August 9 at streamgages 05471000 South Skunk River below Squaw Creek near Ames (fig. 1, site 6) and 05471050 South Skunk River at Colfax (fig. 1, site 8). Flooding began on August 10 and August 14 at streamgages 05470000 South Skunk River near Ames (fig. 1, site 4) and 05471500 South Skunk River near Oskaloosa (fig. 1, site 10), respectively. The peak discharges at two of these streamgages occurred on August 11 (fig. 4). The flood peaked at streamgage 05470000 South Skunk River near Ames at 11:45 a.m. with a discharge of $14,800 \mathrm{ft}^{3} / \mathrm{s}$, and at 10:00 a.m. for streamgage 05471000 South Skunk River below Squaw Creek near Ames with a discharge of 36,200 $\mathrm{ft}^{3} / \mathrm{s}$ (fig. 4). The peak discharge of streamgage 05471050 South Skunk River at Colfax of $24,000 \mathrm{ft}^{3} / \mathrm{s}$ occurred on August 14 at 1:30 a.m. and the peak discharge of streamgage 05471500 South Skunk River near Oskaloosa of 25,200 $\mathrm{ft}^{3} / \mathrm{s}$ occurred on August 16 at 1:30 a.m. (fig. 4). The 2010 flood is the largest known flood at the following streamgages: 05470000 South Skunk River near Ames, 05471000 South Skunk River below Squaw Creek near Ames, and 05471050 South Skunk River at Colfax. The annual flood-probability range of the 2010 flood at the streamgages 05470000 South Skunk River near Ames and 05471050 South Skunk River at Colfax is estimated to be 0.2 to 1 percent (table 3 ). At streamgage 05471000 South Skunk River below Squaw Creek, the annual 
Table 6. Magnitude and annual probability of theoretical rainfall amounts for selected storm periods in the Central, South-Central, and Southeast lowa Climatological Divisions.

[Rainfall amounts from Huff and Angel (1992)]

\begin{tabular}{|c|c|c|c|c|}
\hline \multirow{2}{*}{$\begin{array}{c}\text { Duration } \\
\text { (hours) }\end{array}$} & \multicolumn{4}{|c|}{ Rainfall (inches) for indicated probabilities } \\
\hline & 10 (percent) & 4 (percent) & 2 (percent) & 1 (percent) \\
\hline \multicolumn{5}{|c|}{ Central } \\
\hline 24 & 4.27 & 5.15 & 5.87 & 6.61 \\
\hline 48 & 4.67 & 5.75 & 6.52 & 7.33 \\
\hline 72 & 5.16 & 6.22 & 7.06 & 8.12 \\
\hline 120 & 5.72 & 6.92 & 7.98 & 9.18 \\
\hline 240 & 7.22 & 8.61 & 9.66 & 10.88 \\
\hline \multicolumn{5}{|c|}{ South-Central } \\
\hline 24 & 4.65 & 5.78 & 6.73 & 7.74 \\
\hline 48 & 5.06 & 6.28 & 7.35 & 8.60 \\
\hline 72 & 5.64 & 6.90 & 7.96 & 9.24 \\
\hline 120 & 6.26 & 7.64 & 8.78 & 9.99 \\
\hline 240 & 7.57 & 8.99 & 10.09 & 11.04 \\
\hline \multicolumn{5}{|c|}{ Southeast } \\
\hline 24 & 4.67 & 5.67 & 6.58 & 7.59 \\
\hline 48 & 5.20 & 6.35 & 7.32 & 8.40 \\
\hline 72 & 5.74 & 6.95 & 7.88 & 8.98 \\
\hline 120 & 6.32 & 7.60 & 8.69 & 9.95 \\
\hline 240 & 7.35 & 8.45 & 9.33 & 10.42 \\
\hline
\end{tabular}

flood-probability range is estimated to be less than 0.2 percent (table 3). The 2010 flood is the second largest known flood at the streamgage 05471500 South Skunk River near Oskaloosa, with the annual flood-probability range of 1 to 2 percent (table 3). Peak discharges at the four streamgages shown in figure 4 were determined from stage-discharge rating curves that were verified by discharge measurements made near the time of occurrence of the respective peaks. In addition to the four streamgages shown in figure 4 , the 2010 flood also is the second largest known flood at the streamgage 05470500 Squaw Creek at Ames (fig. 1, site 5), where the annual probability of the peak discharge of $22,400 \mathrm{ft}^{3} / \mathrm{s}$ on August 11 is estimated to be less than 0.2 percent (table 3 ).

For informational purposes, also shown on the four hydrographs, are the discharges corresponding to the National Weather Service (NWS) designated flood stage effective in 2010 during the flood (fig. 4). The flood stages represent "an established gage height for a given location at which a rise in water-surface level begins to impact lives, property, or commerce" (U.S. Department of Commerce, National Oceanic and Atmospheric Administration, and National Climatic Data Center, 2010c). In February 2012 and effective March 14, 2012, NWS in Des Moines changed the designated flood stage at three of the four river forecast locations shown in figure 4 (U.S. Department of Commerce, National Oceanic and
Atmospheric Administration, and National Weather Service, 2012a). The flood stage was not changed at steamgage 05471500 South Skunk River near Oskaloosa. The discharges corresponding to the NWS flood stages in effect prior to February 2012 were determined from the respective USGS stagedischarge rating curves in use at the time of the flood.

At streamgage 05470000 South Skunk River near Ames, the NWS flood stage was 14.0 feet (ft) (discharge 7,030 ft 3 ). This is the stage at which water affects East 13th Street between Meadow Lane and the bridge over the South Skunk River (U.S. Department of Commerce, National Oceanic and Atmospheric Administration, and National Weather Service, 2012b). The streamgage South Skunk River near Ames was above flood stage during August 10-12, and the peak stage of $19.04 \mathrm{ft}$ (table 3) exceeded the flood stage by $5.04 \mathrm{ft}$. The NWS flood stage was changed to $12.5 \mathrm{ft}$ in March 2012.

At streamgage 05471000 South Skunk River below Squaw Creek near Ames, the NWS flood stage was $20.0 \mathrm{ft}$ (discharge $6,200 \mathrm{ft}^{3} / \mathrm{s}$ ). This is the stage at which water affects agricultural land from Ames to Cambridge (U.S. Department of Commerce, National Oceanic and Atmospheric Administration, and National Weather Service, 2012b). The streamgage South Skunk River below Squaw Creek near Ames was above flood stage during August 9-13, and the peak stage of $26.72 \mathrm{ft}$ (table 3 ) exceeded the flood stage by $6.72 \mathrm{ft}$. The NWS flood stage was changed to $21.5 \mathrm{ft}$ in March 2012.

At streamgage 05471050 South Skunk River at Colfax, the NWS flood stage was $17 \mathrm{ft}$ (discharge $6,710 \mathrm{ft}^{3} / \mathrm{s}$ ). At a stage of $15.5 \mathrm{ft}$, storm sewers in the city of Colfax are closed and water affects nearby agricultural land; at a stage of $19 \mathrm{ft}$, the earthen levee is overtopped near the Iowa 117 bridge and the first two downtown blocks of Colfax adjacent to the river are inundated (U.S. Department of Commerce, National Oceanic and Atmospheric Administration, and National Weather Service, 2012b). The streamgage South Skunk River at Colfax was above flood stage during August 9-17, and the peak stage of $23.85 \mathrm{ft}$ (table 3 ) exceeded the flood stage by $6.85 \mathrm{ft}$. The NWS flood stage was changed to $18 \mathrm{ft}$ in March 2012.

At streamgage 05471500 South Skunk River near Oskaloosa, the NWS flood stage is $24.5 \mathrm{ft}$ (discharge 19,500 $\mathrm{ft}^{3} / \mathrm{s}$ ), the stage at which State Highway Iowa 92 east of Oskalooosa is threatened (U.S. Department of Commerce, National Oceanic and Atmospheric Administration, and National Weather Service, 2012b). The streamgage South Skunk River near Oskaloosa was above flood stage during August 13-16, and the peak stage of $26.40 \mathrm{ft}$ (table 3) exceeded the flood stage by $1.90 \mathrm{ft}$.

\section{Chronology of Flood Effects}

The following flood description information was obtained from newspaper articles posted online by the Associated Press (Welte, 2010), the Epoch Times (Wu, 2010) and the Des Moines Register (Beeman and Petroski, 2010; Belz, 2010), and from online sources obtained from the U.S. Department 

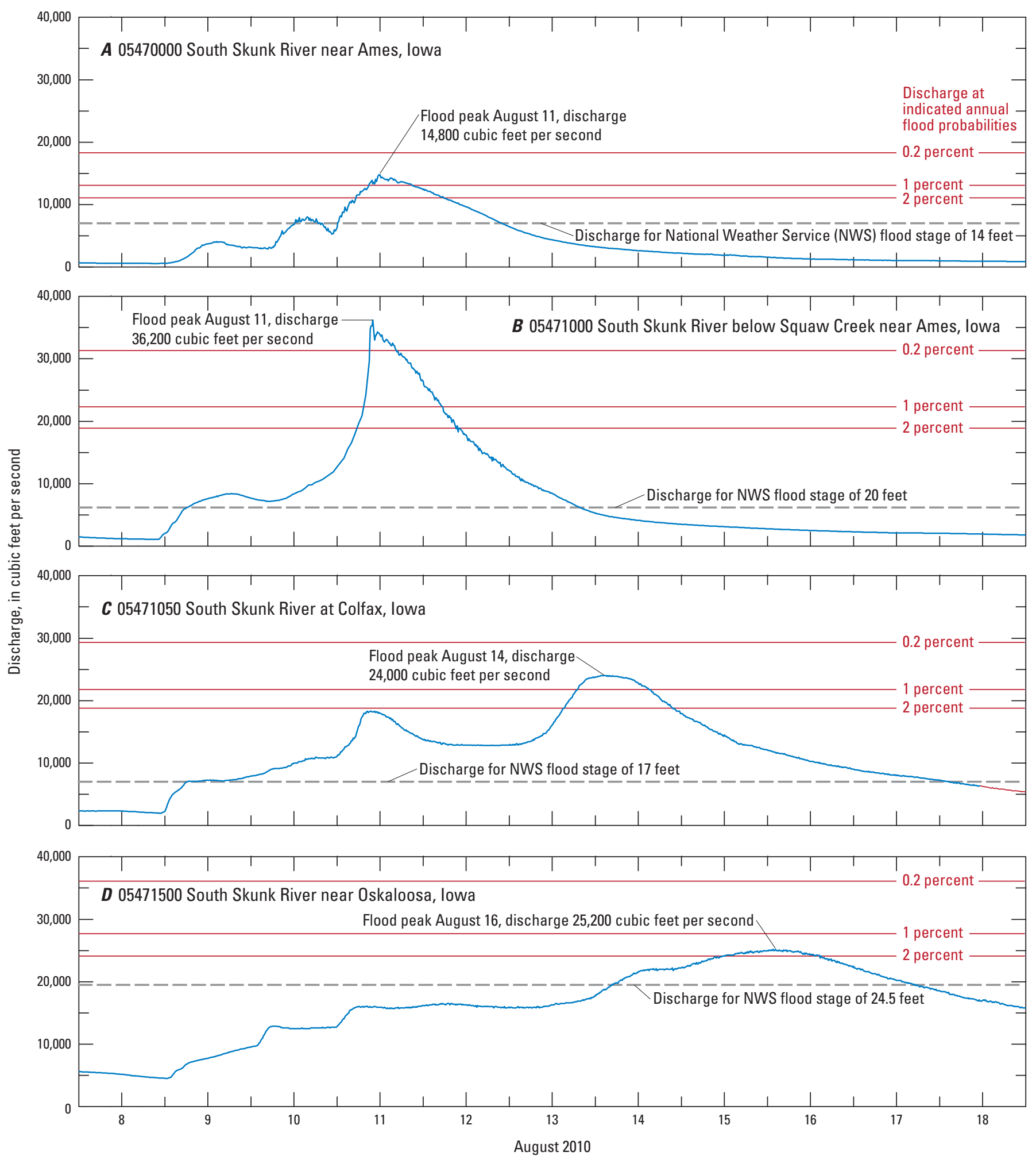

Figure 4. Discharge hydrographs for four streamgages on the South Skunk River, August 8-18, 2010. 
of Commerce, National Oceanic and Atmospheric Administration, and National Climatic Data Center (2010a).

"Strong thunderstorms and heavy rains fell in central Iowa for three consecutive nights from August 8 to 10, causing extreme flooding. Polk County reported flash flooding in the 4300 block of Fairview near Dean Avenue and flood waters washed away railroad tracks and caused a derailment. The Iowa Department of Transportation closed Interstate 35 just south of Ames (mile post 97), and both lanes of U.S. Highway 30 in the area also were closed. Increasing rain on the evening of August 10 caused the evacuation of several hundred people from their homes in Ames and also claimed the life of a 16-year old female early in the morning on August 11, when three cars were swept away by raging floodwaters on a rural road between Altoona and Mitchellville (not located on a figure). The water treatment plant in Ames was inundated and was shut down on August 11 after a series of eight main breaks dropped pressure. Major damage also was done to several buildings on the Iowa State Campus, with damage estimates around 40-50 million dollars. Hilton Coliseum reported 4 to $6 \mathrm{ft}$ of water inside and Cy Stephens Auditorium reported water in the mechanical building up to the first floor. Downriver from Ames, the town of Colfax was nearly cut off by the rising South Skunk River and again, several hundred people were evacuated from their homes."

\section{Flood Profile}

To develop profiles of the 2010 flood for the South Skunk River, the USGS measured HWMs at 20 locations. The HWMs used in the profile were measured at all Federal and State Highway bridges, at USGS streamgages, and at selected county and local bridges. The HWMs at bridges were located immediately downstream from the bridge and one bridge-length upstream from the bridge. The distances between most of the profile points are less than about $10 \mathrm{mi}$ (fig. 1). The distance between U.S. Highway 63 and County Road T33 on the South Skunk River is about 11.3 mi. River miles were determined using a geographic information system (GIS) (ESRI, 2012) to measure the distance along the South Skunk River reach from its confluence with the North Skunk River (not located on a figure) and using USGS 1:24,000-scale topographic-map data (U.S. Geological Survey, 2011b).

The HWMs were surveyed to bench marks (see appendix) at bridges within 1 week of the flood peak, and were later referenced to the National Geodetic Vertical Datum of 1929 (NGVD 29) by differential leveling or differential positioning using a global positioning system (GPS). In addition, bridge deck, low-bridge chord, and reference-point elevations were measured with respect to the bench marks. The elevations for the bridge deck and low-bridge chord generally were measured on the lowest end of the bridge. The reference points were established so that low-flow water-surface elevations could be measured by using a weight suspended on a measuring tape. Low-flow water-surface elevations were obtained August 17-18, 2011, to indicate a typical range in stage along the river and to define the low-water slope.

The HWMs profiled in figures 5-10 and listed in table 7 are an average of HWMs measured at each location. The profile lines connecting the HWMs in the figures approximate the flood elevation between marks. The lines do not account for any intermediate features that could affect flood elevation, such as channel morphology or bridges and dams where HWMs were not measured. Primary highways referenced in the report are shown in figure 1; secondary roads are not shown in the figure.

The August 11-16, 2010, flood along the South Skunk River is profiled from County Road V67/280th Avenue, northeast of Ollie in Keokuk County upstream to West Riverside Road in Ames. The 128-mi river reach is shown in figure 1, and the 20 stream sites where HWMs were measured are listed in table 7.

HWMs profiled for the July 1993 flood were obtained from U.S. Army Corps of Engineers (1994) for the reach downstream of Interstate 35 (river mile 123.34) with the exception of the HWMs for USGS streamgages 05471050 and 05471500 , which were obtained from "Floods of June 17, 1990, and July 9, 1993, along Squaw Creek and the South Skunk River in Ames, Iowa, and vicinity" (Einhellig and Eash, 1996). HWMs for the June 1990 flood from USGS streamgage 05471000 , U.S. Highway 30 upstream to USGS streamgage 05470000, West Riverside Road in Ames also were obtained from Einhellig and Eash (1996). For the June 1975 flood, HWMs from County Road T22/240th Place upstream to USGS streamgage 05470000 , West Riverside Road in Ames were obtained from "Floods in the Skunk River Basin, Iowa" (Heinitz and Wiitala, 1978). HWMs for the May 1944 flood were obtained from U.S. Army Corps of Engineers (1994) from the Keokuk-Mahaska county line upstream to USGS streamgage 05470000 , West Riverside Road, Ames. All HWMs listed in table 7 are shown as part of the profile lines in figures 5-10 for the South Skunk River. Also shown are low-flow profiles measured in August 2011, March 1976 (Heinitz and Wiitala, 1978; from County Road V67/280th Avenue upstream to Interstate 80), July 1975 (Heinitz and Wiitala, 1978; from USGS streamgage 05471050, State Highway 117 upstream to E. 13th Street, Ames), and July 1995 (Einhellig and Eash, 1996; from Interstate 35 upstream to USGS streamgage 05470000, West Riverside Road, Ames).

At the streamgage 05471500 South Skunk River near Oskaloosa (fig. 1, site 10), the 2010 flood peak was higher than the 1944 flood peak by about $0.6-1.4 \mathrm{ft}$ (depending on whether the 1944 HWM was obtained on the upstream or downstream side of the bridge; table 7); however, the peak discharge was less than the 1944 flood discharge. This difference between stage and discharge for the 1944 and 2010 floods is most likely because of continuing flood-plain and channel aggradation at the Oskaloosa location (Eash, 1996). 
Table 7. Locations and elevations of high-water marks used in the South Skunk River flood profile of August 11-16, 2010.

[HWM, high-water mark; NGVD 29, National Geodetic Vertical Datum of 1929; USGS, U.S. Geological Survey; ND, not determined]

\begin{tabular}{clcc}
\hline $\begin{array}{c}\text { Distance from mouth } \\
\text { (river miles) }\end{array}$ & \multicolumn{1}{c}{ Location } & $\begin{array}{c}\text { Downstream HWM } \\
\text { (feet above NGVD 29) }\end{array}$ & $\begin{array}{c}\text { Upstream HWM } \\
\text { (feet above NGVD 29) }\end{array}$ \\
\hline 4.24 & County Road V67/280th Avenue, northeast of Ollie & 647.34 & 648.68 \\
7.19 & County Road V5G, north of Ollie & 651.99 & 652.40 \\
17.15 & State Highway 149, northeast of Martinsburg & 664.91 & 666.23 \\
22.16 & 180th Avenue, southwest of Hayesville & 671.76 & 672.51 \\
30.53 & State Highway 21, south of Delta & 683.17 & 684.25 \\
39.61 & County Road V13/Ventura Avenue, south of Rose Hill & 695.58 & 696.46 \\
42.35 & State Highway 92, east of Oskaloosa & 698.38 & 698.76 \\
51.14 & USGS streamgage 05471500, U.S. Highway 63, north of Oskaloosa & 711.90 & 712.70 \\
62.48 & County Road T33, south of Peoria between Pella and New Sharon & 727.93 & 729.78 \\
70.92 & County Road T14, north of Pella & 742.83 & 742.91 \\
75.15 & County Road F70/Spencer Street, southwest of Galesburg & 749.05 & 749.41 \\
84.69 & State Highway 14, south of Newton & 768.61 & 768.95 \\
95.06 & USGS streamgage 05471050, State Highway 117, Colfax & 793.85 & 794.07 \\
97.52 & Interstate 80, west of Colfax & 796.21 & 797.14 \\
104.20 & U.S. Highway 65, northeast of Bondurant & 814.40 & ND \\
109.31 & County Roads S14/F22/NE Yoder Drive, east of Elkhart & 827.40 & 827.94 \\
115.82 & State Highway 210, southeast of Cambridge & 848.08 & 849.18 \\
123.34 & Interstate 35, southeast of Ames & 871.83 & 872.27 \\
126.94 & USGS streamgage 05471000, U.S. Highway 30, Ames & 883.82 & 885.07 \\
132.39 & USGS streamgage 05470000, West Riverside Road, Ames & 907.65 & ND \\
\hline
\end{tabular}

\section{Summary}

As a result of intense periods of rainfall August 8-11, 2010, major flooding occurred in the South Skunk River Basin during August 11-16. On August 11, 96-hour rainfall amounts recorded at Ames and Story City were 9.61 and 8.70 inches, respectively. The majority of the rainfall occurred during a 48-hour period. Within the South Skunk River Basin, peak discharges of 14,800 cubic feet per second ( $\mathrm{ft}^{3} / \mathrm{s}$ ) (annual flood-probability estimate of 0.2 to 1 percent) at the 05470000 South Skunk River near Ames; of 36,200 $\mathrm{ft}^{3} / \mathrm{s}$ (annual floodprobability estimate of less than 0.2 percent) at the 05471000 South Skunk River below Squaw Creek near Ames streamgage (both on August 11, 2010); and of 24,000 ft $\mathrm{ft}^{3} / \mathrm{s}$ (annual floodprobability estimate of 0.2 to 1 percent) at the 05471050 South Skunk River at Colfax streamgage on August 14, 2010, are the largest floods on record for these sites. Peak discharges of $22,400 \mathrm{ft}^{3} / \mathrm{s}$ (annual flood-probability estimate of less than 0.2 percent) at the 05470500 Squaw Creek at Ames, and of $25,200 \mathrm{ft}^{3} / \mathrm{s}$ (annual flood-probability estimate of 1 to 2 percent) at the 05471500 South Skunk River near Oskaloosa, streamgages are the second highest floods on record at these sites.

\section{References Cited}

Beeman, Perry, and Petroski, William, 2010, After flood, Ames faces water crisis: The Des Moines Register, accessed November 7, 2011, at http://www.desmoinesregister.com/ article/20100813/NEWS/8130358/Ames-faces-water-crisis.

Belz, Adam, 2010, River drops in Colfax, but cleanup has to wait: The Des Moines Register, accessed November 7, 2011, at http://www.desmoinesregister.com/ article/20100813/NEWS/8130356/1001/NEWS/River-dropsin-Colfax-but-cleanup-has-to-wait.

Cohn, T.A., Berenbrock, Charles, Kiang, J.E., and Mason, R.R., Jr., 2012, Calculating weighted estimates of peak streamflow statistics: U.S. Geological Survey Fact Sheet 2012-2038, 4 p. (Also available at http://pubs.usgs.gov/ $f_{S} / 2012 / 3038 /$.)

Eash, D.A., 1996, Flood-plain and channel aggradation of selected bridge sites in the Iowa and Skunk River Basins, Iowa: U.S. Geological Survey Water-Resources Investigations Report 95-4290, 44 p. 
Eash, D.A., 1997, Effects of the 1993 flood on the determination of flood magnitude and frequency in Iowa: U.S. Geological Survey Circular 1120-K, 23 p. (Also available at http://pubs.er.usgs.gov/usgspubs/cir/cir1120K.)

Eash, D.A., 2001, Techniques for estimating flood-frequency discharges for streams in Iowa: U.S. Geological Survey Water-Resources Investigations Report 00-4233, 88 p. (Also available at http://pubs.er.usgs.gov/usgspubs/wri/ wri004233.)

Einhellig, R.F., and Eash, D.A., 1996, Floods of June 17, 1990, and July 9, 1993, along Squaw Creek and the South Skunk River in Ames, Iowa, and vicinity: U.S. Geological Survey Open-File Report 96-249, 34 p.

ESRI, 2012, ArcGIS Desktop: Release 10, Redlands, CA: Environmental Systems Research Institute.

Federal Emergency Management Agency, 2010, Federal Register Notice, accessed July 6, 2011, at http://www.fema.gov/ news/event.fema? id=13099; http://www.fema.gov/pdf/news/ pda/1930.pdf.

Heinitz, A.J., and Wiitala, S.W., 1978, Floods in the Skunk River Basin, Iowa: U.S. Geological Survey Open-File Report 79-272, 80 p.

Hillaker, H.J., 2010a, Iowa Annual Weather Summary - 2010, accessed January 10, 2012, at http://www.iowaagriculture. gov/climatology/weatherSummaries/2010/fas2010.pdf.

Hillaker, H.J., 2010b, Iowa Monthly Weather Summary August 2010, accessed January 10, 2012, at http://www. iowaagriculture.gov/climatology/weatherSummaries/2010/ fms201008.pdf.

Hillaker, H.J., 2010c, Iowa climate review: Des Moines, Iowa, Iowa Department of Agriculture and Land Stewardship, v. 24 , no. 8,21 p.

Holmes, R.R., Jr., and Dinicola, K., 2010, 100-year flood-It's all about chance: U.S. Geological Survey General Information Product 106, 1 p.

Huff, F.A., and Angel, J.R., 1992, Rainfall frequency atlas of the Midwest: Champaign, Ill., Illinois State Water Survey, Bulletin 71, 141 p. (Also available at http://www.isws. illinois.edu/pubdoc/B/ISWSB-71.pdf.)

Interagency Advisory Committee on Water Data, 1982, Guidelines for determining flood flow frequency: Reston, Va., Hydrology Subcommittee Bulletin 17B, 28 p. and appendixes. (Also available at http://water.usgs.gov/osw/ bulletin17b/bulletin_17B.html.)
Iowa Homeland Security and Management, 2010, Press Releases, accessed February 28, 2011 at http://www. iowahomelandsecurity.org/documents/releases/2010/ RELEASE_081310.pdf; http://www.iowahomelandsecurity. org/documents/releases/2010/RELEASE_081510.pdf; http:// www.iowahomelandsecurity.org/documents/releases/2010/ RELEASE_081610.pdf; http://www.iowahomelandsecurity. org/documents/releases/2010/RELEASE_082310-2.pdf.

Lara, O.G., and Heinitz, A.J., 1976, Flood of June 27, 1975 in City of Ames, Iowa: U.S. Geological Survey Open-File Report 76-728, 56 p.

Leica Geosystems, 2010, IaRTN SmartNET Connection List, Leica Spiderweb, St. Gallen, Switzerland, accessed October 25, 2012, at http://spiderweb.iartn.com/spiderweb/ frmIndex.aspx.

Oschwald, W.R., Riecken, F.F., Dideriksen, R.I., Scholtes, W.H., and Schaller, F.W., 1965, Principal soils of Iowa: Ames, Iowa, Iowa State University, Department of Agronomy, Special Report no. 42, 77 p.

Prior, J.C., 1991, Landforms of Iowa: Iowa City, University of Iowa Press, $154 \mathrm{p}$.

Prior, J.C., Kohrt, C.J., and Quade, D.J., 2009, The landform regions of Iowa: Iowa Geological Survey, Iowa Department of Natural Resources, Iowa City, Iowa, accessed July 2011, at ftp://ftp.igsb.uiowa.edu/gis_library/ia_state/geologic/ landform/landform_regions.zip.

U.S. Army Corps of Engineers, 1966, Flood plain information report on Skunk River and Squaw Creek, Story County, Iowa: Rock Island, Ill., U.S. Army Engineer District.

U.S. Army Corps of Engineers, 1975, Flood plain information report on Skunk River above Ames, Iowa: Rock Island, Ill., U.S. Army Engineer District.

U.S. Army Corps of Engineers, 1994, The great flood of 1993 post-flood report: U.S. Army Engineers, North Central Division, appendix B, plates 89-96, accessed June 15, 2012, at http://www.mvr.usace.army.mil/PublicAffairsOfficel HistoricArchives/Floodof1993/Appendix\%20B/Plates.pdf, plates 91-96.

U.S. Department of Commerce, National Oceanic and Atmospheric Administration, and National Climatic Data Center, 2004, National Geodetic Survey at http://www.ngs.noaa. gov/TOOLS/Vertcon/vertcon.html.

U.S. Department of Commerce, National Oceanic and Atmospheric Administration, and National Climatic Data Center, 2010a, National Climatic Data Center Storm Events, accessed January 10, 2012, at http://www.ncdc.noaa.gov/ stormevents/. 
U.S. Department of Commerce, National Oceanic and Atmospheric Administration, and National Climatic Data Center, 2010b, Hourly precipitation data, Iowa, August 2010: Asheville, N.C., Monthly Summaries, v. 60, no. 8, 19 p.

U.S. Department of Commerce, National Oceanic and Atmospheric Administration, and National Climatic Data Center, 2010c, National Weather Service Manual 10-950, accessed April 4, 2012 at http://www.weather.gov/directives/sym/ pd01009050curr.pdf.

U.S. Department of Commerce, National Oceanic and Atmospheric Administration, and National Weather Service, 2012a, accessed March 28, 2012, at http://www.crh.noaa. gov/images/dmx/hydro/PNSDMX_20120206_Various_ SvcChanges_FS_FloodCats_FINAL.pdf

U.S. Department of Commerce, National Oceanic and Atmospheric Administration, and National Weather Service, 2012b, accessed April 5, 2012, at http://waterweather. gov/ahps2/hydrograph.php?wfo=dmx\&gage=amei4, http://water.weather.gov/ahps2/hydrograph.

php? wfo $=$ dmx\&gage =aesi4, http://water.weather. gov/ahps 2/hydrograph.php? wfo $=d m x \& g a g e=c f x i 4$, and http://water.weather.gov/ahps2/hydrograph. php?wfo $=$ dmx\&gage $=$ ooai4 .
U.S. Geological Survey, 2005, accessed March 29, 2011, at http://pubs.usgs.gov/wdr/2005/wdr-il-05/misc/peakcods. htm.

U.S. Geological Survey, 2011a, National Water Information System (NWISWeb): U.S. Geological Survey database, accessed April 20, 2011, at http://waterdata.usgs.gov/nwis/ sw.

U.S. Geological Survey, 2011b, The National Map, accessed January 5, 2011, at http://nationalmap.gov/ustopo/index. html.

Welte, Melanie S., 2010, Iowa teen dies in raging floods as hundreds flee: Associated Press, accessed November 7, 2011, at http://www.aolnews.com/2010/08/11/flooding-kills1-in-iowa-hundreds-evacuated/.

$\mathrm{Wu}$, Cheryl, 2010, Iowa flooding in Ames breaks records: The Epoch Times, accessed November 7, 2011, at http://www. theepochtimes.com/n2/united-states/iowa-flooding-in-amesbreaks-records-40794.html. 
Figures 5-10 




Figure 5. Profile of the August 11-16, 2010, flood for the South Skunk River, river miles 4 to 133. 


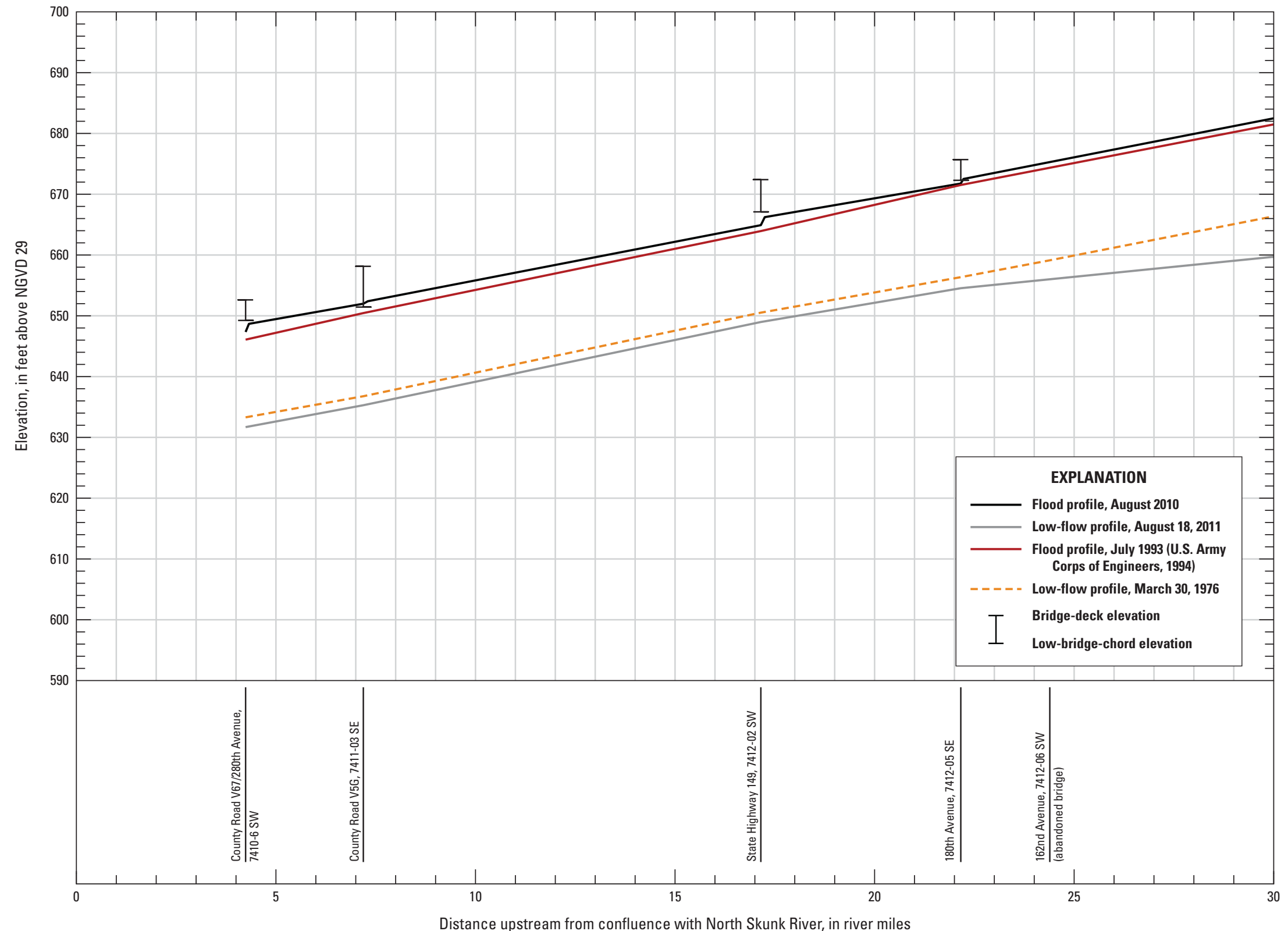

Figure 6. Profile of the August 11-16, 2010, flood for the South Skunk River, river miles 4 to 30. 


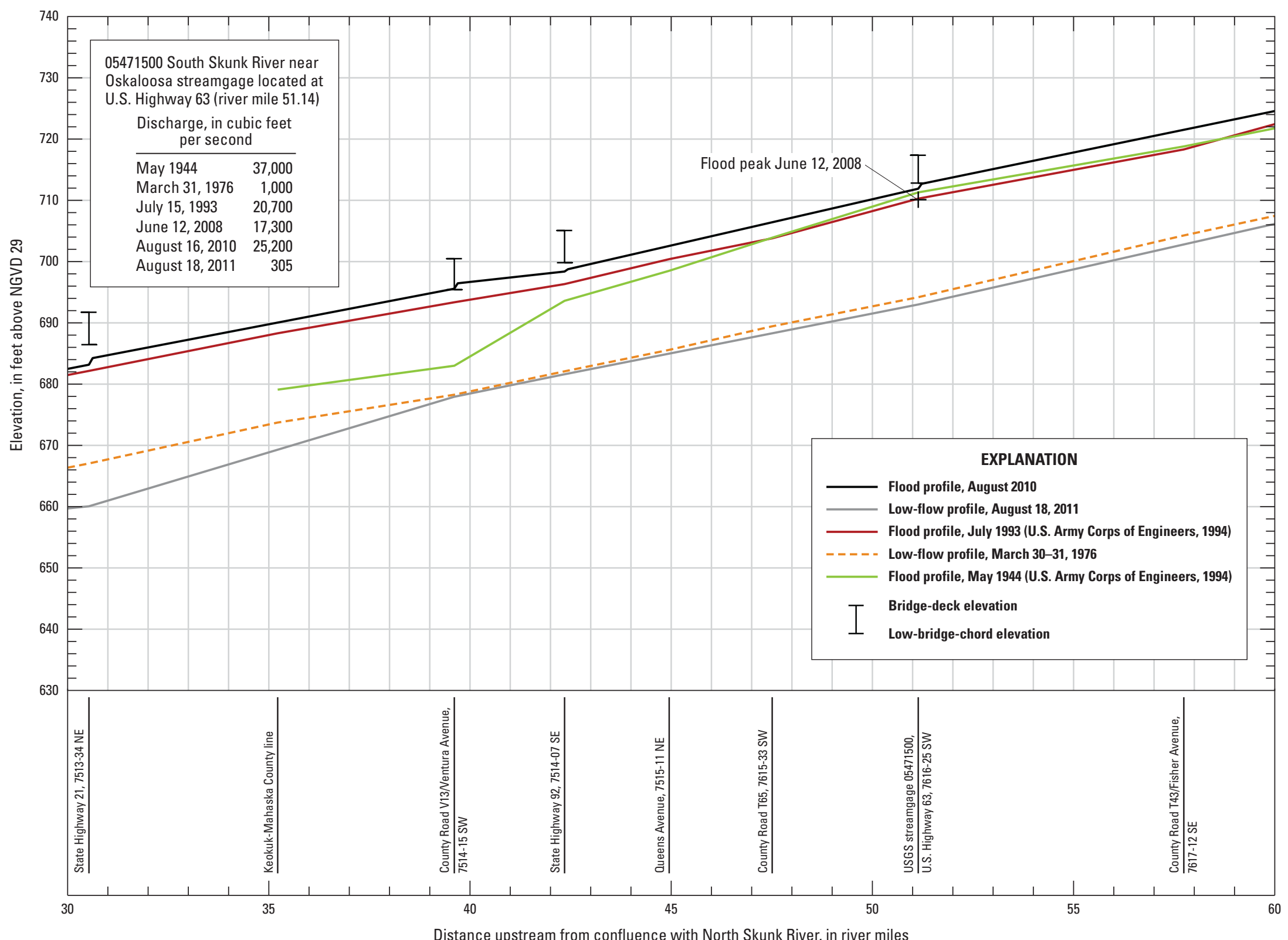

Figure 7. Profile of the August 11-16, 2010, flood for the South Skunk River, river miles 30 to 60. 


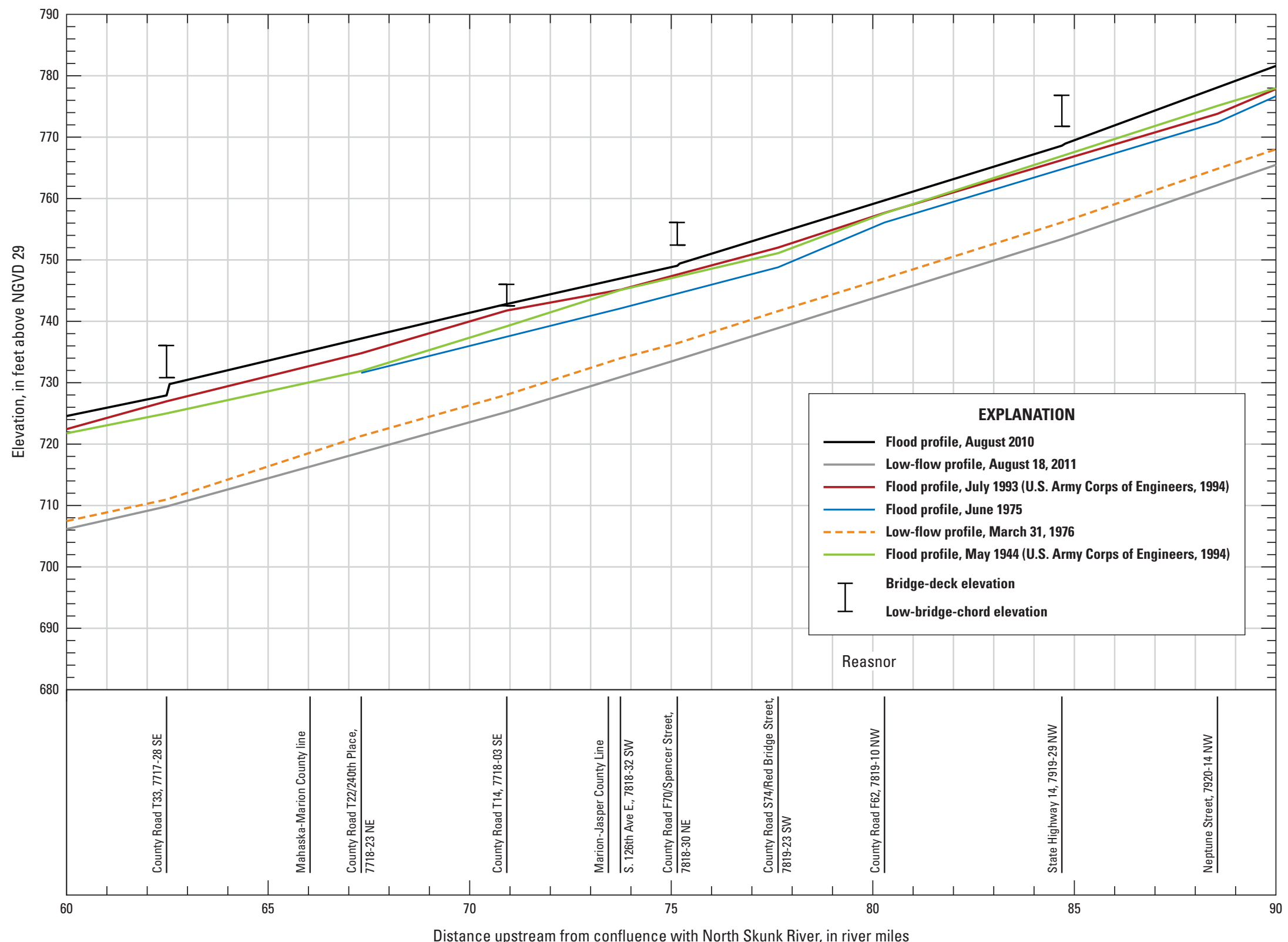

Figure 8. Profile of the August 11-16, 2010, flood for the South Skunk River, river miles 60 to 90 . 


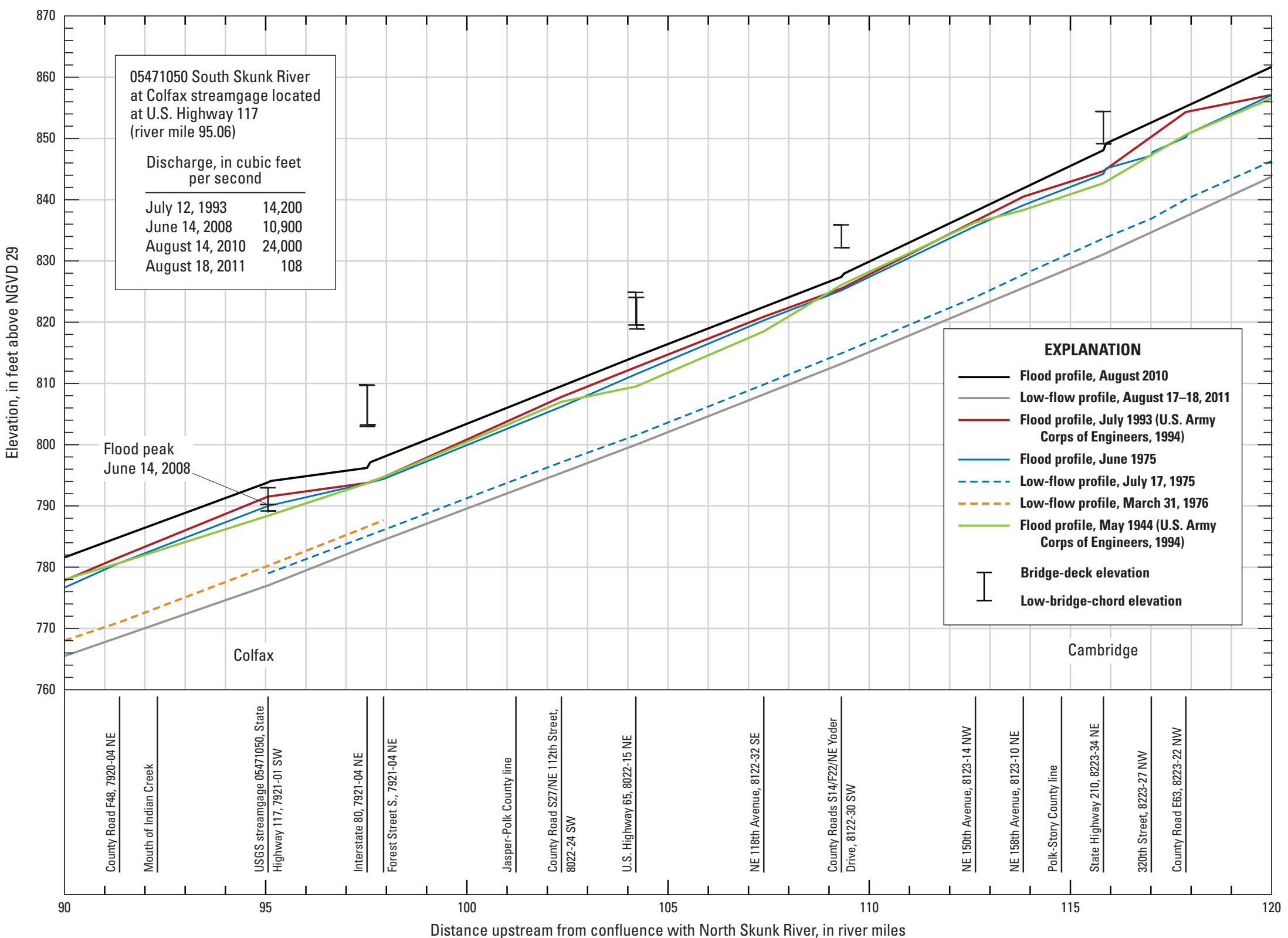

Figure 9. Profile of the August 11-16, 2010, flood for the South Skunk River, river miles 90 to 120. 


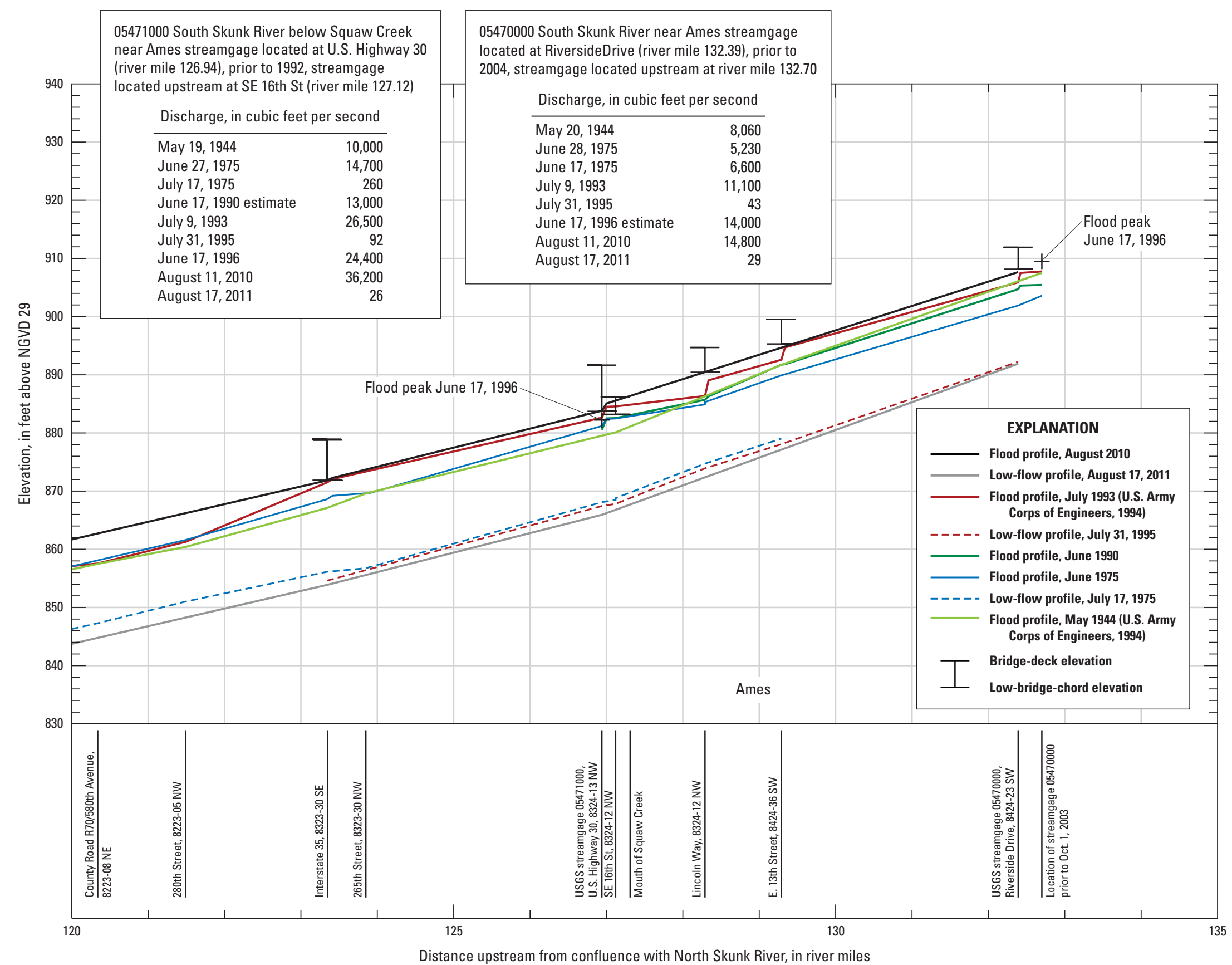

Figure 10. Profile of the August 11-16, 2010, flood for the South Skunk River, river miles 120 to 133. 


\section{Appendix. List of Bench Marks and Reference Points}

To facilitate measuring and referencing the high-water marks (HWMs) used in the flood profiles to a common datum, bench marks (BMs), temporary bench marks (TBMs), and reference points (RPs) were found or established by the U.S. Geological Survey (USGS) at selected bridges along the profiled river reach. All BM, TBM, and RP elevations listed in table 1-1 are referenced to the National Geodetic Vertical Datum of 1929. The list of 20 sites where the USGS measured HWMs for the August 2010 flood is shown in table 7. Of these 20 sites, BMs or TBMs are listed for all of the sites and RPs are listed for 15 of the sites in table 1-1. For 10 of the 20 sites listed in this table, elevations for BMs were established by another agency and this agency is listed in table 1-1. At USGS streamgages, BMs or TBMs are identified as reference marks (RMs) that are listed in appendix table 1-1 with a RM number. $\mathrm{BM}, \mathrm{TBM}$, and RP elevations established by the USGS were determined from a combination of global positioning system (GPS) technology and differential leveling. For 10 of the 20 sites listed in this table, elevations were established by the USGS using GPS and are noted in the BM, TBM, and RP descriptions. GPS data were collected by the USGS using Real Time Kinematic (RTK) surveys. RTK surveys of GPS data were processed using the IaRTN SmartNet, a Global Navigation Satellite System (GNSS) reference station network service provided by Iowa Department of Transportation and Leica Geosystems (Leica Geosystems, 2010). The quality of the RTK GPS data is based on an average of multiple sets of GPS data collected using satellite configurations spaced at least 30 minutes apart, and on comparisons of elevations between RTK GPS surveys of GPS BMs and published elevations.

In general, BMs are points that were specifically designed to mark an elevation, such as USGS elevation disks and Iowa DOT BMs (round-top rods embedded in concrete at one or more corners of a bridge). Marks, such as squares and crosses that were chiseled or filed on concrete or metal, were used as TBMs or RPs. RPs were established to permit water-surface elevations to be determined by use of a tape and weight. The terms "right" and "left" in the descriptions are determined as viewed while facing in the downstream direction.

The BMs, TBMs, and RPs are designated by an index number or legal description derived from their respective locations using Public Land Survey System coordinates (township, range, section). Within the section, the quarter section in which the BM, TBM, or RP is located is designated by northeast (NE), southeast (SE), northwest (NW), and southwest (SW). For example, T74N R10W $06 \mathrm{SW}$ refers to a location in Township 74 North, Range 10 West, southwest quarter of section 06. A number in parentheses following the quartersection designation indicates the number of the BM, TBM, or $\mathrm{RP}$ in that particular quarter section. The index number serves to describe the legal description of the mark without further reference in the body of the description. The physical location of the BM or TBM on a bridge dictates the appropriate legal description. The RPs, and any additional BMs or TBMs, are listed with the related BMs or TBMs and are identified by the same legal description though, at times, they are in a different section, range, or township as determined by upstream or downstream location.

The BMs, TBMs, and RPs are listed in table 1-1 in upstream order for the South Skunk River. The user of this information is cautioned that BMs, TBMs, and RPs listed herein might have been disturbed, destroyed, or moved since elevations were established. It is the responsibility of the user to determine the condition and the suitability of the BM, TBM, or RP. 
Table 1-1. Bench marks and reference points used in the August 11-16, 2010, South Skunk River flood profile.

[Bench marks and reference points are listed in upstream order. NGVD 29, National Geodetic Vertical Datum of 1929, BM, bench mark; TBM, temporary bench mark; RP, reference point; GPS, Global Positioning System; T, township; R, range; N, north; W, west; S, south; E, east; RM, reference mark; a number in parentheses following the quarter-section designation indicates the sequence number of the BM, TBM, or RP in that particular quarter section; an RM designation with a number in parentheses following a Mark description indicates the RM is located at a U.S. Geological Survey streamgage site]

\begin{tabular}{|c|c|c|c|c|c|}
\hline $\begin{array}{l}\text { Public Land Survey } \\
\text { System (township, range, } \\
\text { section, quarter section) }\end{array}$ & $\begin{array}{l}\text { Mark } \\
\text { classification }\end{array}$ & Location & Mark & $\begin{array}{l}\text { Elevation } \\
\text { in feet } \\
\text { (NGVD 1929) }\end{array}$ & $\begin{array}{l}\text { Elevation } \\
\text { determination } \\
\text { method }\end{array}$ \\
\hline T74N R10W 06 SW (1) & TBM & $\begin{array}{l}\text { About } 3.25 \text { miles northeast of Ollie, at County Road V67/280th Avenue } \\
\text { bridge over the South Skunk River, on left upstream concrete wing- } \\
\text { wall. }\end{array}$ & Chiseled square & 655.29 & GPS \\
\hline T74N R10W 06 SW (2) & $\mathrm{RP}$ & $\begin{array}{l}\text { About } 3.25 \text { miles northeast of Ollie, at County Road V67/280th Avenue } \\
\text { bridge over the South Skunk River, just right of } 5 \text { th drain hole from } \\
\text { right downstream side of bridge, on end of guardrail post. }\end{array}$ & Filed arrow & 655.28 & GPS \\
\hline T74N R11W 03 SE (1) & TBM & $\begin{array}{l}\text { About } 2.75 \text { miles north of Ollie, at County Road V5G bridge over the } \\
\text { South Skunk River, on left downstream concrete guard rail. }\end{array}$ & Chiseled square & 660.56 & GPS \\
\hline T74N R11W 03 SE (2) & $\mathrm{RP}$ & $\begin{array}{l}\text { About } 2.75 \text { miles north of Ollie, at County Road V5G bridge over the } \\
\text { South Skunk River, in middle of } 4 \text { th concrete section from left down- } \\
\text { stream end of bridge. }\end{array}$ & Chiseled square & 660.61 & GPS \\
\hline T74N R12W 02 SW (1) & $\mathrm{BM}$ & $\begin{array}{l}\text { About } 4.25 \text { miles northeast of Martinsburg, at U.S. Highway } 149 \text { bridge } \\
\text { over the South Skunk River, on left upstream concrete guardrail. }\end{array}$ & $\begin{array}{l}\text { Iowa Department } \\
\text { of Transportation } \\
\text { bench mark }\end{array}$ & 674.97 & GPS \\
\hline T74N R12W 02 SW (2) & $\mathrm{RP}$ & $\begin{array}{l}\text { About } 4.25 \text { miles northeast of Martinsburg, at U.S. Highway } 149 \text { bridge } \\
\text { over the South Skunk River, at 6th drain hole from left downstream } \\
\text { end of bridge. }\end{array}$ & Chiseled square & 676.27 & GPS \\
\hline T74N R12W 05 SE (1) & TBM & $\begin{array}{l}\text { About } 1.75 \text { miles southwest of Hayesville, at 180th Street bridge over } \\
\text { the South Skunk River, on left downstream wingwall. }\end{array}$ & Chiseled square & 678.49 & $\begin{array}{l}\text { Elevation surveyed } \\
\text { from } 1 \text { st or } 2 \mathrm{~d} \text { order } \\
\text { BM }\end{array}$ \\
\hline T74N R12W 05 SE (2) & $\mathrm{RP}$ & $\begin{array}{l}\text { About } 1.75 \text { miles southwest of Hayesville, at } 180 \text { th Street bridge over } \\
\text { the South Skunk River, on 35th guardrail post from right downstream } \\
\text { end of bridge. }\end{array}$ & Filed arrow & 680.22 & Surveyed from TBM \\
\hline T75N R13W 34 NE (1) & BM & $\begin{array}{l}\text { About } 3.75 \text { miles south of Delta, on U.S. Highway } 21 \text { bridge over the } \\
\text { South Skunk River, on left upstream concrete guardrail. }\end{array}$ & $\begin{array}{l}\text { Iowa Department } \\
\text { of Transportation } \\
\text { bench mark }\end{array}$ & 694.34 & GPS \\
\hline T75N R13W 34 NE (2) & $\mathrm{RP}$ & $\begin{array}{l}\text { About } 3.75 \text { miles south of Delta, on U.S. Highway } 21 \text { bridge over the } \\
\text { South Skunk River, at } 5 \text { th drain hole from left downstream side of } \\
\text { bridge. }\end{array}$ & Chiseled square & 694.67 & GPS \\
\hline T75N R14W 15 SW (1) & TBM & $\begin{array}{l}\text { About } 1.4 \text { miles south of Rose Hill, on County Road V13/Ventura } \\
\text { Avenue bridge over the South Skunk River, on left upstream concrete } \\
\text { guardrail. }\end{array}$ & Chiseled square & 703.19 & GPS \\
\hline T75N R14W 15 SW (2) & $\mathrm{RP}$ & $\begin{array}{l}\text { About } 1.4 \text { miles south of Rose Hill, on County Road V13/Ventura } \\
\text { Avenue bridge over the South Skunk River, at } 5 \text { th drain hole from left } \\
\text { downstream end of bridge. }\end{array}$ & Chiseled square & 706.10 & GPS \\
\hline
\end{tabular}


[Bench marks and reference points are listed in upstream order. NGVD 29, National Geodetic Vertical Datum of 1929, BM, bench mark; TBM, temporary bench mark; RP, reference point; GPS, Global Positioning System; T, township; R, range; N, north; W, west; S, south; E, east; RM, reference mark; a number in parentheses following the quarter-section designation indicates the sequence number of the BM, TBM, or RP in that particular quarter section; an RM designation with a number in parentheses following a Mark description indicates the RM is located at a U.S. Geological Survey streamgage site]

\begin{tabular}{|c|c|c|c|c|c|}
\hline $\begin{array}{l}\text { Public Land Survey } \\
\text { System (township, range, } \\
\text { section, quarter section) }\end{array}$ & $\begin{array}{c}\text { Mark } \\
\text { classification }\end{array}$ & Location & Mark & $\begin{array}{l}\text { Elevation } \\
\text { in feet } \\
\text { (NGVD 1929) }\end{array}$ & $\begin{array}{l}\text { Elevation } \\
\text { determination } \\
\text { method }\end{array}$ \\
\hline T75N R14W 07 SE (1) & $\mathrm{BM}$ & $\begin{array}{l}\text { About } 5.75 \text { miles east of Oskaloosa, on U.S. Highway } 92 \text { bridge over the } \\
\text { South Skunk River, on right downstream concrete guardrail. }\end{array}$ & $\begin{array}{l}\text { Iowa Department } \\
\text { of Transportation } \\
\text { bench mark }\end{array}$ & 707.60 & GPS \\
\hline T75N R14W 07 SE (2) & $\mathrm{RP}$ & $\begin{array}{l}\text { About } 5.75 \text { miles east of Oskaloosa, on U.S. Highway } 92 \text { bridge over } \\
\text { the South Skunk River, at } 3 \mathrm{~d} \text { drain hole from left downstream side of } \\
\text { bridge. }\end{array}$ & Chiseled square & 708.64 & GPS \\
\hline T76N R16W 25 SW (1) & TBM & $\begin{array}{l}\text { About } 3.4 \text { miles north of Oskaloosa, site of streamgage } 05471500 \text { South } \\
\text { Skunk River near Oskaloosa, on U.S. Highway } 63 \text { bridge over the } \\
\text { South Skunk River, on right upstream wingwall. }\end{array}$ & Chiseled cross & 719.97 & $\begin{array}{l}\text { Streamgage elevation } \\
\text { data }\end{array}$ \\
\hline T77N R17W 28 SE (1) & $\mathrm{BM}$ & $\begin{array}{l}\text { Between Pella and New Sharon, on County Road T33 bridge over the } \\
\text { South Skunk River, on left downstream wingwall. }\end{array}$ & $\begin{array}{l}\text { Iowa Department } \\
\text { of Transportation } \\
\text { bench mark }\end{array}$ & 738.38 & GPS \\
\hline T77N R18W 03 SE (1) & $\mathrm{BM}$ & $\begin{array}{l}\text { About } 4.8 \text { miles north of Pella, on County Road T14 bridge over the } \\
\text { South Skunk River, on left upstream concrete guardrail. }\end{array}$ & $\begin{array}{l}\text { Marion County } \\
\text { bench mark }\end{array}$ & 748.47 & $\begin{array}{l}\text { Elevation supplied by } \\
\text { Marion County }\end{array}$ \\
\hline T77N R18W 03 SE (2) & $\mathrm{RP}$ & $\begin{array}{l}\text { About } 4.8 \text { miles north of Pella, on County Road T14 bridge over the } \\
\text { South Skunk River, at end of 5th concrete section of guardrail from } \\
\text { left downstream end of bridge. }\end{array}$ & Chiseled square & 750.62 & Surveyed from BM \\
\hline T78N R18W 30 NE (1) & TBM & $\begin{array}{l}\text { About } 2.3 \text { miles southwest of Galesburg, on County Road F70/Spencer } \\
\text { Street bridge over the South Skunk River, on right upstream wheel- } \\
\text { guard. }\end{array}$ & Chiseled square & 759.87 & $\begin{array}{l}\text { Elevation surveyed } \\
\text { from } 1 \text { st or } 2 \mathrm{~d} \text { order } \\
\text { BM }\end{array}$ \\
\hline T78N R18W 30 NE (2) & $\mathrm{RP}$ & $\begin{array}{l}\text { About } 2.3 \text { miles southwest of Galesburg, on County Road F70/Spen- } \\
\text { cer Street bridge over the South Skunk River, at 3d drain from right } \\
\text { downstream end of bridge, on metal guardrail. }\end{array}$ & 3 filed marks & 760.78 & Surveyed from TBM \\
\hline T79N R19W 29 NW (1) & TBM & $\begin{array}{l}\text { About } 4.2 \text { miles south of Newton, on U.S. Highway } 14 \text { bridge over the } \\
\text { South Skunk River, on left downstream wheelguard. }\end{array}$ & Chiseled square & 778.33 & $\begin{array}{l}\text { Elevation surveyed } \\
\text { from } 1 \text { st or } 2 \mathrm{~d} \text { order } \\
\text { BM }\end{array}$ \\
\hline T79N R19W 29 NW (2) & $\mathrm{RP}$ & $\begin{array}{l}\text { About } 4.2 \text { miles south of Newton, on U.S. Highway } 14 \text { bridge over the } \\
\text { South Skunk River, just right of } 3 \mathrm{~d} \text { drain from left downstream end of } \\
\text { bridge. }\end{array}$ & 2 chiseled lines & 778.56 & Surveyed from TBM \\
\hline T79N R21W 01 SW (1) & $\mathrm{BM}$ & $\begin{array}{l}\text { At north edge of Colfax, site of streamgage } 05471050 \text { South Skunk } \\
\text { River at Colfax, on State Highway } 117 \text { bridge over the South Skunk } \\
\text { River, on left upstream abutment. }\end{array}$ & $\begin{array}{l}\text { Iowa Department } \\
\text { of Transportation } \\
\text { bench mark (RM3) }\end{array}$ & 796.86 & $\begin{array}{l}\text { Streamgage elevation } \\
\text { data }\end{array}$ \\
\hline T79N R21W 04 NE (1) & TBM & $\begin{array}{l}\text { About } 2 \text { miles west of Colfax, on Interstate } 80 \text { bridge over the South } \\
\text { Skunk River (downstream bridge), on right downstream abutment. }\end{array}$ & Chiseled cross & 809.62 & GPS \\
\hline
\end{tabular}


Table 1-1. Bench marks and reference points used in the August 11-16, 2010, South Skunk River flood profile.-Continued

[Bench marks and reference points are listed in upstream order. NGVD 29, National Geodetic Vertical Datum of 1929, BM, bench mark; TBM, temporary bench mark; RP, reference point; GPS, Global Positioning System; T, township; R, range; N, north; W, west; S, south; E, east; RM, reference mark; a number in parentheses following the quarter-section designation indicates the sequence number of the BM, TBM, or RP in that particular quarter section; an RM designation with a number in parentheses following a Mark description indicates the RM is located at a U.S. Geological Survey streamgage site]

\begin{tabular}{|c|c|c|c|c|c|}
\hline $\begin{array}{l}\text { Public Land Survey } \\
\text { System (township, range, } \\
\text { section, quarter section) }\end{array}$ & $\begin{array}{c}\text { Mark } \\
\text { classification }\end{array}$ & Location & Mark & $\begin{array}{l}\text { Elevation } \\
\text { in feet } \\
\text { (NGVD 1929) }\end{array}$ & $\begin{array}{l}\text { Elevation } \\
\text { determination } \\
\text { method }\end{array}$ \\
\hline T79N R21W 04 NE (2) & $\mathrm{RP}$ & $\begin{array}{l}\text { About } 2 \text { miles west of Colfax, on Interstate } 80 \text { bridge over the South } \\
\text { Skunk River (downstream bridge), at 4th drain hole from right down- } \\
\text { stream end of bridge. }\end{array}$ & Chiseled square & 812.69 & GPS \\
\hline T80N R22W 15 NE (1) & $\mathrm{BM}$ & $\begin{array}{l}\text { About } 4 \text { miles northeast of Bondurant, on U.S. Highway } 65 \text { bridge over } \\
\text { the South Skunk River (upstream bridge), on left upstream guardrail. }\end{array}$ & $\begin{array}{l}\text { Iowa Department } \\
\text { of Transportation } \\
\text { bench mark }\end{array}$ & 826.72 & GPS \\
\hline T80N R22W 15 NE (2) & $\mathrm{RP}$ & $\begin{array}{l}\text { About } 4 \text { miles northeast of Bondurant, on U.S. Highway } 65 \text { bridge over } \\
\text { the South Skunk River (downstream bridge), at 4th drain hole from } \\
\text { left downstream end of bridge, on curb. }\end{array}$ & Chiseled square & 826.38 & GPS \\
\hline T81N R22W 30 SW (1) & TBM & $\begin{array}{l}\text { About } 3 \text { miles east of Elkhart, on County Road S14/F22/NE Yoder Drive } \\
\text { bridge over the South Skunk River, on right downstream abutment, } \\
0.7 \text { feet below road. }\end{array}$ & Chiseled square. & 835.20 & $\begin{array}{l}\text { Elevation surveyed } \\
\text { from } 1 \text { st or } 2 \mathrm{~d} \text { order } \\
\mathrm{BM}\end{array}$ \\
\hline T81N R22W 30 SW (2) & TBM & $\begin{array}{l}\text { About } 3 \text { miles east of Elkhart, on County Road S14/F22/NE Yoder Drive } \\
\text { bridge over the South Skunk River, on left downstream abutment. }\end{array}$ & Penny in concrete & 835.13 & $\begin{array}{l}\text { Elevation surveyed } \\
\text { from TBM at T81N } \\
\text { R22W } 30 \mathrm{SW}(1)\end{array}$ \\
\hline T81N R22W 30 SW (3) & $\mathrm{RP}$ & $\begin{array}{l}\text { About } 3 \text { miles east of Elkhart, on County Road S14/F22/NE Yoder Drive } \\
\text { bridge over South Skunk River, at } 3 \mathrm{~d} \text { downstream guardrail post left } \\
\text { of center pier, on top of right side of post. }\end{array}$ & Chiseled arrow & 839.23 & $\begin{array}{l}\text { Elevation surveyed } \\
\text { from } 1 \text { st or } 2 \mathrm{~d} \text { order } \\
\mathrm{BM}\end{array}$ \\
\hline T82N R23W 34 NE (1) & $\mathrm{BM}$ & $\begin{array}{l}\text { About } 1.6 \text { miles southeast of Cambridge, on U.S. Highway } 210 \text { bridge } \\
\text { over the South Skunk River, on right downstream wingwall. }\end{array}$ & $\begin{array}{l}\text { Iowa Department } \\
\text { of Transportation } \\
\text { bench mark }\end{array}$ & 857.04 & GPS \\
\hline T82N R23W 34 NE (2) & $\mathrm{RP}$ & $\begin{array}{l}\text { About } 1.6 \text { miles southeast of Cambridge, on U.S. Highway } 210 \text { bridge } \\
\text { over the South Skunk River, between } 2 \mathrm{~d} \text { and } 3 \mathrm{~d} \text { drain holes from left } \\
\text { downstream end of bridge, on concrete guardrail. }\end{array}$ & Chiseled square & 857.40 & GPS \\
\hline T83N R23W 30 SE (1) & $\mathrm{BM}$ & $\begin{array}{l}\text { About } 4.5 \text { miles southeast of Ames, on Interstate } 35 \text { bridge over the } \\
\text { South Skunk River (downstream bridge), on top of right downstream } \\
\text { wingwall. }\end{array}$ & $\begin{array}{l}\text { Iowa Department } \\
\text { of Transportation } \\
\text { bench mark }\end{array}$ & 879.53 & $\begin{array}{l}\text { Elevation surveyed } \\
\text { from } 1 \text { st or } 2 \mathrm{~d} \text { order } \\
\text { BM }\end{array}$ \\
\hline T83N R23W 30 SE (2) & $\mathrm{RP}$ & $\begin{array}{l}\text { About } 4.5 \text { miles southeast of Ames, on Interstate } 35 \text { bridge over the } \\
\text { South Skunk River, at } 3 \mathrm{~d} \text { drain hole from left downstream end of } \\
\text { bridge, on concrete guardrail. }\end{array}$ & Chiseled square & 880.18 & $\begin{array}{l}\text { Elevation surveyed } \\
\text { from BM }\end{array}$ \\
\hline T83N R24W 13 NW (1) & TBM & $\begin{array}{l}\text { About } 2 \text { miles southeast of Ames, site of streamgage } 05471000 \text { South } \\
\text { Skunk River below Squaw Creek near Ames, on U.S. Highway } 30 \\
\text { bridge over the South Skunk River, on right upstream wingwall. }\end{array}$ & $\begin{array}{l}\text { Chiseled square } \\
\text { (RM9) }\end{array}$ & 891.19 & $\begin{array}{l}\text { Streamgage elevation } \\
\text { data }\end{array}$ \\
\hline T84N R24W 23 SW (1) & $\mathrm{BM}$ & $\begin{array}{l}\text { At northern edge of Ames, site of streamgage } 05470000 \text { South Skunk } \\
\text { River near Ames, on West Riverside Road bridge over the South } \\
\text { Skunk River, on right upstream wingwall. }\end{array}$ & $\begin{array}{l}\text { Iowa Department } \\
\text { of Transporta- } \\
\text { tion bench mark } \\
\text { (RM16) }\end{array}$ & 914.53 & $\begin{array}{l}\text { Streamgage elevation } \\
\text { data }\end{array}$ \\
\hline
\end{tabular}


Publishing support provided by the:

Denver and Rolla Publishing Service Centers

For more information concerning this publication, contact:

Director, USGS Iowa Water Science Center

P.O. Box 1230

lowa City, IA 52244

(319) 337-4191

Or visit the lowa Water Science Center Web site at: http://ia.water.usgs.gov 



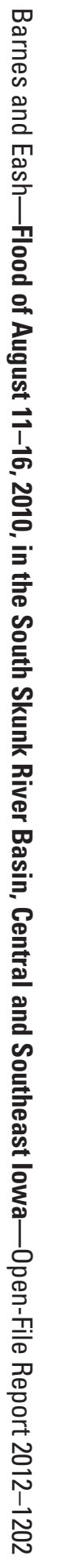

ISBN 778-1-4113-351b-5 